\title{
Greater bioavailability of chelated compared with inorganic zinc in broiler chicks in the presence or absence of elevated calcium and phosphorus
}

This article was published in the following Dove Press journal:

Open Access Animal Physiology

25 June 2015

Number of times this article has been viewed

\section{James D Richards \\ Paula M Fisher \\ Joseph L Evans \\ Karen JWedekind}

Research and Development Department, Novus International Inc., Saint Charles, MO, USA
Correspondence: Karen J Wedekind Research and Development Department, Novus International Inc., 20 Research Park Drive, Saint Charles 63304, MO, USA

Tel + I 6369267442

Fax + I 6369267449

Email karen.wedekind@novusint.com

\begin{abstract}
Animal diets often contain antagonists that reduce $\mathrm{Zn}$ bioavailability, thereby creating a deficiency. The bioavailability of Zn chelated to 2-hydroxy-4-(methylthio)butanoic acid (chelated $\mathrm{Zn}$ ) was compared with $\mathrm{Zn}$ sulfate in broiler chicks in two dietary conditions: a Zn-deficient corn-soybean meal (C-SBM) diet and a Zn-deficient C-SBM diet containing elevated Ca and $\mathrm{P}$ as antagonists. In experiment 1 , chicks were fed a common diet (19 $\mathrm{mg} \mathrm{Zn/kg} \mathrm{diet)} \mathrm{through}$ day 8 , and then a $\mathrm{Zn}$-unsupplemented ( $21 \mathrm{mg} \mathrm{Zn} / \mathrm{kg}$ diet; $0.82 \% \mathrm{Ca}, 0.47 \%$ available P) C-SBM basal or the basal supplemented with 5, 10, 15, 20, or $30 \mathrm{mg} \mathrm{Zn/kg} \mathrm{diet} \mathrm{as} \mathrm{chelated} \mathrm{Zn}$ or $\mathrm{Zn}$ sulfate for 6 days. Common-intercept, multiple linear regression slope-ratio analysis indicated significantly greater $\mathrm{Zn}$ bioavailability for chelated $\mathrm{Zn}$ relative to $\mathrm{Zn}$ sulfate as judged by: total tibia $\mathrm{Zn}(\mu \mathrm{g})(161 \% ; P=0.001)$; tibia zinc concentration $(\mu \mathrm{g} / \mathrm{g} ; 165 \%, P=0.0009)$; and small intestinal metallothionein mRNA expression (248\%; $P=0.009)$. In experiment 2 , chicks were fed a Zn-deficient ( $24 \mathrm{mg} \mathrm{Zn/kg} \mathrm{diet)} \mathrm{common} \mathrm{diet,} \mathrm{then} \mathrm{fed} \mathrm{a} \mathrm{C-SBM} \mathrm{basal} \mathrm{elevated} \mathrm{in} \mathrm{Ca}$ and $\mathrm{P}$ (27 $\mathrm{mg} \mathrm{Zn} / \mathrm{kg}$ diet; $1.2 \% \mathrm{Ca}, 1 \%$ available $\mathrm{P}$ ), or the basal supplemented with 15 or 30 $\mathrm{mg} \mathrm{Zn/kg} \mathrm{diet} \mathrm{as} \mathrm{Zn} \mathrm{sulfate} \mathrm{or} \mathrm{7.5,} \mathrm{15,} \mathrm{or} 30 \mathrm{mg} \mathrm{Zn/kg} \mathrm{diet} \mathrm{as} \mathrm{chelated} \mathrm{Zn}$. Zn sulfate was antagonized to a greater extent than $\mathrm{Zn}$ chelate. Bioavailability of chelated $\mathrm{Zn}$ relative to $\mathrm{Zn}$ sulfate was $441 \%$ ( $P=0.0063$; $\mu$ g total tibia $\mathrm{Zn}), 307 \%(P=0.0066 ; \mu \mathrm{g} / \mathrm{g}$ tibia $\mathrm{Zn})$, and $426 \%$ ( $P=0.0041$; metallothionein). Thus, feeding chelated $\mathrm{Zn}$ offers advantages over inorganic $\mathrm{Zn}$, especially in diets containing high levels of $\mathrm{Ca}$ and $\mathrm{P}$, which is a common occurrence in pet food and in livestock diets.
\end{abstract}

Keywords: antagonism, broilers, chelate, metallothionein, minerals

\section{Introduction}

Zinc impacts a wide variety of functions, including gene expression, DNA and protein synthesis, cell signaling, cell division and animal growth, immune development and function, synthesis of structural proteins such as collagen and keratin, bone and tissue development, reproduction, and defense against oxidative stress. ${ }^{1-11}$ Deficiency or marginal Zn status can negatively impact one or more of these processes. As such, Zn is supplemented in virtually all animal diets, either as inorganic trace mineral (ITM) salts (such as sulfates, chlorides, and oxides), and/or organic trace minerals (OTMs). While ITMs are inexpensive, it is generally accepted that they suffer from relatively poor bioavailability compared when with some OTMs, primarily due to the numerous antagonisms and interactions between the ITMs and other components of the digesta, such as phytic acid and fiber. ${ }^{10,12,13}$ Other types of $\mathrm{Zn}$ antagonisms have been reported, including excesses of $\mathrm{Ca}$ and/or $\mathrm{P}^{10,14-16}$

The antagonistic effect of excess $\mathrm{Ca}$ on $\mathrm{Zn}$ utilization is widely known, especially in the presence of phytate. ${ }^{17}$ Few studies, however, have evaluated the effects of $\mathrm{P}$ excess 
on $\mathrm{Zn}$ bioavailability, and the results of these studies have been inconsistent. ${ }^{18}$ Studies demonstrating detrimental effects of excess $\mathrm{P}$ concluded that both $\mathrm{Ca}$ and $\mathrm{P}$ excess antagonized $\mathrm{Zn}$ independently of each other, but that the combination of $\mathrm{Ca}$ and $\mathrm{P}$ were additive. ${ }^{14,15,19} \mathrm{In}$ addition, $\mathrm{Zn}$ antagonism occurred under both balanced and unequal $\mathrm{Ca}: \mathrm{P}$ ratios. According to Heth et al, Ca decreased $\mathrm{Zn}$ absorption in the presence of $1 \%$ dietary $\mathrm{P}$, but not when $\mathrm{P}$ was $0.3 \%-0.5 \%{ }^{15}$ Furthermore, detrimental effects of $\mathrm{P}$ occurred for both phytic acid $\mathrm{P}$ and inorganic $\mathrm{P}$, and either form of inorganic $\mathrm{P}$ (eg, polyphosphates or orthophosphates) was antagonistic. Other studies, however, failed to show negative effects of $P$ excess on Zn utilization. ${ }^{20-22}$ However, these latter studies suffered from insufficient statistical power, response variables with limited sensitivity to $\mathrm{Zn}$ deficiency, or utilized diets not deficient in $\mathrm{Zn}$, thus having a limited likelihood of observing any effect.

It is widely accepted that a higher degree of nutrition is required to achieve the full genetic and economic potential of today's livestock. Balancing both macrominerals and microminerals is a key component of optimizing nutritional health, whether it is the health of livestock, pets, or humans. Feeding higher levels of trace minerals is not a viable solution because this can lead to lower mineral bioavailability, increase environmental burden, and potentially even decrease animal performance. A more sustainable solution is to feed a more bioavailable source of trace minerals such as OTM. However, the literature indicates that not all OTMs are more available than the ITM salts. ${ }^{23-26}$

Bioavailability can be defined as "the degree to which an ingested nutrient in a particular source is absorbed in a form that can be utilized in metabolism by the animal". ${ }^{27}$ In practice, relative bioavailability value (RBV), or the bioavailability of a nutrient within one source relative to the bioavailability of the same nutrient in a standard source, is measured. Measuring the deposition or storage of minerals into selected tissues is the most common variable measured in trace mineral RBV experiments; for example, tibia $\mathrm{Zn}$ is commonly cited for most Zn RBV studies. ${ }^{23,24,26,28-31}$ In addition, it has been reported that the expression levels of several genes and proteins increase or decrease rapidly depending on the $\mathrm{Zn}$ status of the animal. ${ }^{1}$

Metallothionein (MT) mRNA and protein are both modulated by $\mathrm{Zn}$ absorption and status, and are frequently used as indices of $\mathrm{Zn}$ status or bioavailability in a wide variety of species. ${ }^{1,25,28,32-40}$ The primary objective of the studies described here was to compare the bioavailability of chelated $\mathrm{Zn}$ with that of $\mathrm{Zn}$ sulfate in chicks fed corn-soybean meal (C-SBM) diets both in the absence and presence of elevated
Ca and P. Tibia Zn and small intestinal MT mRNA expression were used to measure $\mathrm{Zn}$ bioavailability.

\section{Materials and methods General}

A $\mathrm{Zn}$ depletion-repletion broiler chick model was used to evaluate $\mathrm{Zn}$ bioavailability. Cobb 500 male broiler chicks were randomly assigned to dietary treatments in a randomized complete block design for each experiment. All birds were placed on a common, low Zn milo-soybean meal (SBM) pre-treatment diet (Table 1, $19 \mathrm{mg} \mathrm{Zn/kg} \mathrm{diet,} \mathrm{experiment} \mathrm{1;}$ $24 \mathrm{mg} \mathrm{Zn/kg} \mathrm{diet,} \mathrm{experiment} \mathrm{2;} \mathrm{Zn} \mathrm{difference} \mathrm{due} \mathrm{to} \mathrm{use}$ of different ingredient lots) on day 0 , and then switched to C-SBM treatment diets (Table 1) on day 8. The treatment diets were a Zn-unsupplemented C-SBM basal, or the basal supplemented with $\mathrm{Zn}$ provided as $\mathrm{Zn}$ sulfate $\left(\mathrm{ZnSO}_{4} \cdot \mathrm{H}_{2} \mathrm{O}\right)$ or Zn methionine hydroxy analog chelate [Zn bis(-2-hydroxy4-(methylthio)butanoic acid; ZnHMTBa; Novus International Inc., Saint Charles, MO, USA]. All diets were formulated based on standard US commercial nutrient specifications as reported in a leading agricultural survey ${ }^{41}$ with two exceptions: in experiment 2 , the $\mathrm{Ca}$ and $\mathrm{P}$ were substantially elevated to provide a dietary antagonism for $\mathrm{Zn}$, and in each trial, the $\mathrm{Zn}$ concentrations of the pre-treatment diet and several treatment diets were below the levels recommended by the National Research Council (NRC; $40 \mathrm{mg}$ Zn/kg diet). ${ }^{42}$ There were six replicates (pens) per treatment, except for the basal (treatment 1 , experiment 1 only) which had 12 replicates, with eight chicks per replicate. The small intestine (jejunum) was collected from one bird per pen $(0,15$, and $30 \mathrm{mg} \mathrm{Zn} / \mathrm{kg}$ diet supplemental Zn treatments; experiment 1) on day 11 (after 3 days on treatment diets) or two birds per pen (all treatments; experiment 2; also day 11) and assayed for MT expression as described below. On day 14 (after 6 days on the treatment diets), the birds were weighed, and the right and left tibias were collected (analyzed separately and averaged) from two birds per pen (all treatments) for $\mathrm{Zn}$ analysis by inductively coupled plasma optical emissions spectrometry, using an internally validated method based on AOAC 985.01. ${ }^{43}$ The timing of the intestinal and tibia collections was based on other published depletion-repletion trials in rodents and birds. ${ }^{25,31,44,45}$ All birds were raised in electrically heated brooders. Each pen was provided with water and an individual feeder. All birds were allowed to consume mash feed and water ad libitum. The animal protocols for all experiments were in accordance with the standard operating procedures of Novus International Inc., and complied with all federal and state statutes ensuring the humane and ethical treatment of experimental animals. All birds were observed at least twice 
daily and mortality was recorded. Body weight, cumulative gain, cumulative (mortality-corrected) gain to feed ratio, feed intake, and mortality were calculated for days $8-14$.

\section{Experiment I}

A total of 576 Cobb 500 male broiler chicks were switched to a C-SBM basal diet after an 8-day pre-feed (analyzed to contain $19 \mathrm{mg} \mathrm{Zn/kg} \mathrm{diet),} \mathrm{and} \mathrm{randomized} \mathrm{to} \mathrm{eleven} \mathrm{dietary}$ treatments using a randomized complete block design. The treatment diets included a Zn-unsupplemented basal (analyzed to contain $21 \mathrm{mg} \mathrm{Zn} / \mathrm{kg}$ diet) or the basal supplemented with $5,10,15,20$, or $30 \mathrm{mg} \mathrm{Zn} / \mathrm{kg}$ diet either as $\mathrm{Zn}$ sulfate or $\mathrm{Zn}$ methionine hydroxy analog chelate. Calcium, available $\mathrm{P}$, and total P were $0.82 \%, 0.47 \%$, and $0.72 \%$, respectively. Phytate concentration was calculated to be $0.94 \%$.

\section{Experiment 2}

A total of $288 \mathrm{Cobb} 500$ male broiler chicks were switched to a C-SBM basal diet after an 8-day pre-feed (analyzed to contain $24 \mathrm{mg} \mathrm{Zn/kg} \mathrm{diet),} \mathrm{and} \mathrm{randomized} \mathrm{to} \mathrm{six} \mathrm{dietary} \mathrm{treat-}$ ments in a randomized complete block design. The treatment diets were a Zn-unsupplemented (analyzed to contain $27 \mathrm{mg}$
$\mathrm{Zn} / \mathrm{kg}$ diet) basal, or the basal supplemented with 15 or $30 \mathrm{mg}$ $\mathrm{Zn} / \mathrm{kg}$ diet as $\mathrm{Zn}$ sulfate or $7.5,15$, or $30 \mathrm{mg} \mathrm{Zn} / \mathrm{kg}$ diet as chelated $\mathrm{Zn}$. In experiment 2, $\mathrm{Ca}(1.2 \%)$ and $\mathrm{P}$ (available, $1 \%$; total, $1.3 \%$ ) were substantially elevated relative to the diets in experiment 1 through the inclusion of dicalcium phosphate. Phytate was calculated to be $0.95 \%$ compared with an analyzed concentration of $1.24 \%$.

\section{Metallothionein gene expression}

A section of jejunum, immediately posterior to the duodenal loop and approximately $10 \mathrm{~cm}$ in length, was collected and rinsed gently with 3-4 $\mathrm{mL}$ of ice-cold saline. The jejunum was cut open lengthwise and placed mucosal side up on a clean cutting board. The mucosa from $6-8 \mathrm{~cm}$ of this section was scraped off with a glass slide and collected into $0.9 \mathrm{~mL}$ of RNAlater (Ambion, Austin, TX, USA), stored at $4{ }^{\circ} \mathrm{C}$ overnight, and then stored at $-20^{\circ} \mathrm{C}$. RNA was isolated twice independently from each sample using the High Pure RNA Tissue Kit (Roche Applied Science, Indianapolis, IN, USA) following the manufacturer's instructions. For each RNA preparation, the concentration of RNA was determined using a spectrophotometer and the concentration of RNA

Table I Composition and nutrient content of pre-feed and test diets (as fed basis)

\begin{tabular}{|c|c|c|c|}
\hline \multirow[t]{2}{*}{ Ingredient } & \multicolumn{3}{|l|}{$\%$} \\
\hline & Pre-feed (experiments I and 2) & Test diet (experiment I) & Test diet (experiment 2) \\
\hline Milo & 54.30 & - & - \\
\hline Corn & - & 60.08 & 49.57 \\
\hline Soybean meal & 15.00 & 34.58 & 39.72 \\
\hline Soy concentrate ${ }^{d}$ & 10.96 & - & - \\
\hline Corn starch & 10.00 & - & - \\
\hline Soybean oil & 3.00 & - & 4.60 \\
\hline Cellulose & 2.45 & - & - \\
\hline Dicalcium phosphate & 1.72 & 1.86 & 4.94 \\
\hline Animal fat & - & 1.86 & - \\
\hline Calcium carbonate & 0.87 & 0.91 & - \\
\hline Methionine hydroxy analoge & 0.53 & 0.09 & 0.33 \\
\hline Sodium bicarbonate & - & - & 0.45 \\
\hline Salt & 0.42 & 0.38 & 0.12 \\
\hline Zn-free mineral mix ${ }^{f}$ & 0.10 & 0.10 & 0.10 \\
\hline L-lysine $\mathrm{HCl}, 78 \%$ & 0.24 & - & 0.09 \\
\hline Magnesium sulfate $7 \mathrm{H}_{2} \mathrm{O}$ & 0.14 & - & - \\
\hline Threonine & 0.12 & - & 0.02 \\
\hline DL-methionine & - & 0.08 & - \\
\hline Vitamin premix ${ }^{g}$ & 0.05 & 0.05 & 0.05 \\
\hline Tryptophan & 0.08 & - & - \\
\hline Ethoxyquin & 0.01 & 0.01 & 0.01 \\
\hline Choline & 0.01 & - & - \\
\hline
\end{tabular}

Notes: a Contains 3,150 kcal/kg ME, 22.5\% CP, $19 \mathrm{mg} / \mathrm{kg} \mathrm{Zn} \mathrm{(analyzed),} \mathrm{experiment} \mathrm{I,} 24 \mathrm{mg} / \mathrm{kg} \mathrm{Zn} \mathrm{(analyzed),} \mathrm{experiment} \mathrm{2,} \mathrm{0.8 \%} \mathrm{Ca,} \mathrm{0.44 \%} \mathrm{available} \mathrm{P;86} \mathrm{bontains}$ $3,000 \mathrm{kcal} / \mathrm{kg} \mathrm{ME}, 22.0 \% \mathrm{CP}, 21 \mathrm{mg} / \mathrm{kg} \mathrm{Zn}$ (analyzed), $0.82 \% \mathrm{Ca}, 0.47 \%$ available P, $0.94 \%$ phytate (predicted); ${ }^{\circ}$ contains 3,07I kcal $/ \mathrm{kg} \mathrm{ME}, 23.0 \% \mathrm{CP}, 27 \mathrm{mg} / \mathrm{kg} \mathrm{Zn}$ (analyzed), $1.2 \% \mathrm{Ca}, 1.0 \%$ available $\mathrm{P},{ }^{86} 1.2 \%$ phytate (analyzed); ${ }^{\mathrm{d}}$ profam $646,84.0 \% \mathrm{CP}$ (ADM Decatur, IL, USA); $88 \%$ methionine hydroxy analog, provides $88 \%$ methionine activity (Novus International Inc.); 'provides per kilogram of diet: Mn $60 \mathrm{mg}$; Cu $8 \mathrm{mg}$; selenium $0.15 \mathrm{mg}$; iron $80 \mathrm{mg}$; iodine $0.35 \mathrm{mg}$; ${ }^{\mathrm{p}} \mathrm{provides}$ the following (mg/kg diet): retinyl acetate, 2.4; cholecalciferol, 0.063; DL- $\alpha$-tocopheryl acetate, I0; vitamin $\mathrm{B}_{12}$ 0.014; riboflavin 6.5; niacin 37.5; pantothenic acid I0.0; menadione 2.0; folic acid 0.9; pyridoxine 3.5; thiamine 1.8; and biotin 0.15.

Abbreviations: $\mathrm{CP}$, crude protein; $\mathrm{ME}$, metabolizable energy. 
was adjusted to a maximum of $0.5 \mathrm{mg} / \mathrm{mL}$ by dilution with elution buffer. The RNA samples were either used immediately, or frozen on dry ice and stored at $-80^{\circ} \mathrm{C}$ until use. First-strand complementary DNA synthesis was performed using the Transcriptor Reverse Transcriptase (Roche Applied Science), using the instructions supplied by the manufacturer. Each first-strand synthesis reaction contained $0.5 \mu \mathrm{g}$ of total RNA. The reverse transcription was performed in a thermocycler using the following program: a 90 -second denaturation step at $95^{\circ} \mathrm{C}$; annealing for 30 seconds at $40^{\circ} \mathrm{C}$; 30 minutes of complementary DNA synthesis at $55^{\circ} \mathrm{C}$; and enzyme inactivation by 5 minutes denaturation at $85^{\circ} \mathrm{C}$. The reaction product was concentrated by ethanol precipitation, rinsed, and dried. The sample was then resuspended in $400 \mu \mathrm{L}$ of nuclease-free water and A260/ A280 was measured to ensure that complementary DNA concentration in each sample would fall within the range of concentration usable by the real time-polymerase chain reaction (PCR) assay.

MT mRNA (normalized by $18 \mathrm{~S}$ rRNA) was measured by real-time PCR, as follows. MT mRNA and 18S rRNA levels were measured by real time-PCR on a Roche LightCycler, using the LightCycler FastStart DNA Master HybProbe Kit (Roche Molecular Systems, Alameda, CA, USA) with $0.5 \mu \mathrm{M}$ of each primer and $0.2 \mu \mathrm{M}$ of each TaqMan probe. Primers and probes are shown in Table 2. The parameters of the assay were 42 cycles of 10 seconds at $95^{\circ} \mathrm{C}$ and 40 seconds at $60^{\circ} \mathrm{C}$. While MT expression is inducible by $\mathrm{Zn}$ in many tissues, 18S rRNA expression was not Zn-inducible (data not shown). MT mRNA levels therefore were normalized in each sample by $18 \mathrm{~S}$ rRNA levels, as a loading control. In addition, each PCR run included a known reference standard, from small intestinal cells from a chick fed a low-Zn diet. Data analysis was performed by RelQuant software (Roche Molecular Systems). This software automatically computes the concentrations between the target (MT) and a standard

Table 2 Oligonucleotide sequences used in real-time PCR assays for metallothionein and I8S rRNA

\begin{tabular}{ll}
\hline Primer/probe & Sequence \\
\hline MT forward primer & 5'-CCTGTGCTGGGTCGT-3' \\
MT reverse primer & 5'-TGCTGGCCGGTTCCT-3' \\
MT TaqMan probe & 5'-FAM-TGCTGCTCCTGCTGCC-BHQI-3' \\
I8S forward primer & 5'-GGCCGCCGGAATACT-3' \\
I8S reverse primer & 5'-TCTTGCGCCGGTCC-3' \\
I8S TaqMan probe & 5'-FAM-CCATGATTAAGAGGGACGGCC- \\
& BHQI-3' \\
\hline
\end{tabular}

Abbreviations: MT, metallothionein; PCR, polymerase chain reaction; rRNA, ribosomal RNA.
(18S rRNA), and then normalizes this ratio to a previously established external reaction standard curve which corrects for the individual reaction efficiency differences between the MT and $18 \mathrm{~S}$ assays. The MT expression level was determined twice for each original intestinal sample (one for each independent RNA preparation), and the two values were averaged.

\section{Statistical analyses}

Pen means were used as the experimental units for all variables evaluated. For performance measures, all analyses of variance were performed using PROC GLM of SAS version 9.1 (SAS Institute Inc., Cary, NC, USA) appropriate for a randomized complete block design. ${ }^{46}$ Statistical differences of treatment means comparisons were made with Fisher's protected least significant difference test. For bioavailability measures, MT and tibia $\mathrm{Zn}$ (total $\mathrm{Zn}$ and $\mathrm{Zn}$ concentration) were regressed on supplemental $\mathrm{Zn}$ intake using predicted dietary $\mathrm{Zn}$ concentrations. $\mathrm{Zn}$ bioavailability was determined using $\mathrm{ZnSO}_{4} \cdot \mathrm{H}_{2} \mathrm{O}$ as a standard by means of multiple linear regression and slope-ratio methodology. ${ }^{47-49}$ Standard errors were calculated for each regression coefficient. In experiment 1, the REG procedure of SAS version 9.1 was used to test whether the relationship between tibia $\mathrm{Zn}$ and supplemental $\mathrm{Zn}$ intake was linear or quadratic for each $\mathrm{Zn}$ source. When the quadratic effect was significant, a non-linear procedure of SAS (PROC NLIN) was used to determine the breakpoint using a model involving two linear splines with a plateau wherein the dependent variable, total tibia $\mathrm{Zn}(\mu \mathrm{g})$ or tibia $\mathrm{Zn}$ concentration $(\mu \mathrm{g} / \mathrm{g})$, was regressed on supplemental $\mathrm{Zn}$ intake $(\mathrm{mg}){ }^{31,50}$ This non-linear model defines both a linear response range and the inflection point. Levels falling below the inflection points were used to determine $\mathrm{Zn}$ bioavailability using the estimate statement of PROC GLM of SAS version 9.1, with $\mathrm{ZnSO}_{4} \cdot \mathrm{H}_{2} \mathrm{O}$ as the standard. Simple linear regression (PROC GLM) was used to compare $\mathrm{ZnSO}_{4}$ slopes between experiments 1 and 2 because tibia $Z n$ concentration intercepts were significantly different between experiments. A non-linear procedure of SAS (PROC NLIN) was used to compare slopes, breakpoints, and plateau values between experiments 1 and 2 for Zn-HMTBa. Statistical differences of treatment mean comparisons were made with Fisher's protected least significance based on a probability of $P<0.05$.

\section{Results}

\section{Experiment I}

There were no significant source or treatment effects on days 8-14 on weight gain, feed conversion, or tibia weight (Table 3). 
Table 3 Response of chicks fed graded levels of Zn sulfate or Zn chelate in a typical C-SBM diet (experiment I) ${ }^{\mathrm{a}, \mathrm{b}}$

\begin{tabular}{|c|c|c|c|c|c|c|c|c|}
\hline \multirow{2}{*}{$\begin{array}{l}\text { Supplemental } \\
\text { Zn, mg/kg }\end{array}$} & \multirow[t]{2}{*}{ Zn source ${ }^{d}$} & \multirow{2}{*}{$\begin{array}{l}\text { Weight } \\
\text { gain, g }\end{array}$} & \multirow{2}{*}{$\begin{array}{l}\text { Gain:feed, } \\
\text { g/kg }\end{array}$} & \multirow{2}{*}{$\begin{array}{l}\text { Tibia } \\
\text { weight }^{c}, \mathrm{~g}\end{array}$} & \multirow{2}{*}{$\begin{array}{l}\text { Supplemental Zn } \\
\text { intake (day 14), } \\
\text { mge-g }^{\text {en }}\end{array}$} & \multicolumn{2}{|l|}{ Tibia $\mathbf{Z n}^{c}$} & \multirow{2}{*}{$\begin{array}{l}\text { MT expression, } \\
\text { relative units }\end{array}$} \\
\hline & & & & & & $\begin{array}{l}\text { concentration } \\
\mu \mathrm{g} / \mathrm{g}^{\mathrm{e}}\end{array}$ & $\begin{array}{l}\text { total } \\
\mu \mathrm{g}^{\mathrm{f}}\end{array}$ & \\
\hline 0 & None & 215 & 630.4 & 1.21 & 0 & 96.8 & 116 & I \\
\hline 5 & $\mathrm{ZnSO}_{4}$ & 215 & 635.5 & 1.33 & 1.7 & 100.3 & 132 & - \\
\hline 10 & $\mathrm{ZnSO}_{4}$ & 217 & 637.9 & 1.23 & 3.4 & 113.3 & 138 & - \\
\hline 15 & $\mathrm{ZnSO}_{4}$ & 230 & 658.8 & 1.37 & 5.2 & 124.3 & 170 & 9.1 \\
\hline 20 & $\mathrm{ZnSO}_{4}$ & 211 & 635.4 & 1.30 & 6.6 & 134.3 & 174 & - \\
\hline 30 & $\mathrm{ZnSO}_{4}$ & 223 & 665.5 & 1.37 & 10.0 & $|4| .3$ & 193 & 10.1 \\
\hline 5 & Zn chelate & 214 & 648.7 & 1.17 & 1.7 & 108.3 & 128 & - \\
\hline 10 & Zn chelate & 207 & 641.4 & 1.33 & 3.2 & 113.7 & $15 \mid$ & - \\
\hline 15 & Zn chelate & 219 & 643.0 & 1.35 & 5.1 & | 44.2 & 193 & 13.2 \\
\hline 20 & Zn chelate & 226 & 662.3 & 1.34 & 6.8 & 152.0 & 202 & - \\
\hline 30 & Zn chelate & 231 & 665.1 & 1.37 & 10.4 & 142.8 & 192 & 25.8 \\
\hline Pooled SEM & & 9 & 11.2 & 0.06 & 0.17 & 5.0 & 8 & 4 \\
\hline
\end{tabular}

Notes: aData represent means of six replicate groups ( 12 replicate groups for the zero supplemental $\mathrm{Zn}$ treatment) of eight male chicks during the period of $8-14$ days post-hatching. Tibia $\mathrm{Zn}$ (both left and right) was measured in two birds per replicate on day I4. MT was measured in one bird per replicate on day II; b $\mathrm{Zn-unsupplemented}$ $\mathrm{C}$-SBM diet contained $2 \mathrm{I} \mathrm{mg} / \mathrm{kg}$ diet of $\mathrm{Zn}, 0.82 \% \mathrm{Ca}$, and $0.47 \%$ available $\mathrm{P}$; ${ }^{\circ}$ Tibia weight and $\mathrm{Zn}$ values are expressed on a dry-bone basis; ${ }^{\text {b both }} \mathrm{ZnSO} \mathrm{O}_{4} \cdot \mathrm{H}_{2} \mathrm{O}$ and $\mathrm{Zn}$ chelate were provided as feed-grade sources. $\mathrm{Zn}$ chelate was in the form of $\mathrm{Zn}$ methionine hydroxy analog (Novus International Inc.); ${ }^{\mathrm{e} u s i n g}$ all levels of $\mathrm{Zn}$ sulfate and the 0,5 , I0, and $15 \mathrm{mg} / \mathrm{kg}$ diet $\mathrm{Zn}$ levels of $\mathrm{Zn}$ chelate, multiple regression of tibia $\mathrm{Zn}$ concentration $(\mu \mathrm{g} / \mathrm{g}, \mathrm{Y})$ on supplemental $\mathrm{Zn}$ intake from $\mathrm{Zn}$ sulfate $\left(\mathrm{X}_{1}\right)$ and $\mathrm{Zn}$ chelate $\left(\mathrm{X}_{2}\right)$ was: $Y=95.6( \pm 2.67)+5.00( \pm 0.534) X_{1}+8.26( \pm I .05 I) X, R^{2}=0.64(n=66)$. Bioavailability of chelated $Z n$ relative to $Z n$ sulfate (I00\%) was I65\% ( $\left.P=0.0009\right)$; ${ }^{f}$ using all levels of $Z n$ sulfate and the $0,5,10$, and $15 \mathrm{mg} / \mathrm{kg}$ diet, $\mathrm{Zn}$ levels of $\mathrm{Zn}$ chelate, multiple regression of total tibia $\mathrm{Zn}(\mu \mathrm{g}, \mathrm{Y})$ on supplemental $\mathrm{Zn}$ intake (mg) from $\mathrm{Zn}$ sulfate $\left(\mathrm{X}_{\mathrm{l}}\right)$ and $\mathrm{Zn}$ chelate $\left(\mathrm{X}_{2}\right)$ was: $\mathrm{Y}=\mathrm{II} 3.7( \pm 4.3)+8.66( \pm 0.87) \mathrm{X}_{1}+\mathrm{I} 3.93( \pm \mathrm{I} .7 \mathrm{I}) \mathrm{X}_{2}, R^{2}=0.67(\mathrm{n}=66)$. Bioavailability of chelated $\mathrm{Zn}$ relative to $\mathrm{Zn}$ sulfate $(\mathrm{I} 00 \%)$ was I6I\% $(P=0.00 \mathrm{I}) ;{ }^{8}$ using only 0,15 , and $30 \mathrm{mg} / \mathrm{kg}$ diet $\mathrm{Zn}$ levels of $\mathrm{Zn}$ sulfate and $\mathrm{Zn}$ chelate, multiple regression of I8S-normalized MT expression (relative units, $Y$ ) on supplemental $\mathrm{Zn}$ intake (mg) from $Z n$ sulfate $\left(X_{1}\right)$ and $Z n$ chelate $\left(X_{2}\right)$ was: $Y=1.82( \pm 2.55)+0.92( \pm 0.46) X_{1}+2.28( \pm 0.45) X_{2}+, R^{2}=0.44(n=36)$. Bioavailability of chelated $Z n$ relative $Z n$ sulfate $(I 00 \%)$ was $248 \%(P=0.009)$.

Abbreviations: C-SBM, corn-soybean meal; SEM, standard error of the mean; MT, metallothionein.

Tibia $\mathrm{Zn}(\mu \mathrm{g})$ was regressed against supplemental $\mathrm{Zn}$ intake (mg) for each source. For Zn sulfate, the relationship between total tibia $\mathrm{Zn}$ and supplemental $\mathrm{Zn}$ intake was linear (Figure 1A; $P<0.0001$ ), whereas for chelated $\mathrm{Zn}$ the relationship was quadratic (Figure 1A; $P=0.0006$ ). A breakpoint of $5.9( \pm 0.77) \mathrm{mg}$ of supplemental $\mathrm{Zn}$ intake was determined for chelated $\mathrm{Zn}$, which equates to $17.4 \mathrm{mg}$ supplemental $\mathrm{Zn} / \mathrm{kg}$ diet (38.4 mg total dietary $\mathrm{Zn} / \mathrm{kg}$ ) for this $\mathrm{Zn}$ source. Levels below the breakpoint for chelated $\mathrm{Zn}(0-15 \mathrm{mg} \mathrm{Zn} / \mathrm{kg}$ diet supplemental $\mathrm{Zn}$ ) and all levels of $\mathrm{Zn}$ sulfate were used to determine the slope (total tibia $\mathrm{Zn}$ regressed on supplemental $\mathrm{Zn}$ intake) for each source using multiple regression. The slopes of the two sources ( $\mathrm{Zn}$ sulfate slope 8.66 ; $\mathrm{Zn}$ chelate slope 13.93), and thus their RBVs were significantly different ( $P=0.001$; Figure $1 \mathrm{~A}$ and Table 3$)$. With the total tibia $\mathrm{Zn}$ response to $\mathrm{Zn}$ sulfate set at $100 \%$, slope-ratio analysis estimated that the RBV of $\mathrm{Zn}$ chelate was $161 \%$ (Figure 1A and Table 3). A similar Zn RBV (165\%, $P=0.0009)$ was also obtained when tibia $\mathrm{Zn}$ concentration $(\mu \mathrm{g} / \mathrm{g})$ was regressed on supplemental Zn intake (mg; Table 3). Small intestinal MT mRNA expression (relative units) was also regressed on supplemental $\mathrm{Zn}$ intake (mg). As with tibia $\mathrm{Zn}$, the slopes of the two sources ( $\mathrm{Zn}$ sulfate slope 0.92 ; $\mathrm{Zn}$ chelate slope $2.28)$, and thus their RBVs were significantly different $(P=0.009$; Figure 1B). With the MT response to Zn sulfate set at $100 \%$, the estimated RBV of $\mathrm{Zn}$ from $\mathrm{Zn}$ chelate was 248\% (Figure 1B and Table 3).

\section{Experiment 2}

There was no Zn source or treatment effect on weight gain, feed efficiency, or tibia weight (Table 4). However, compared with experiment 1 , weight gain and feed intake were substantially reduced as a result of the elevated $\mathrm{Ca}$ and $\mathrm{P}$ levels. Tibia $\mathrm{Zn}$ (both concentration $[\mu \mathrm{g} / \mathrm{g}]$ and total $\mathrm{Zn}[\mu \mathrm{g}]$ ) responded linearly $(P<0.05)$ to supplemental $\mathrm{Zn}$ intake for both $\mathrm{Zn}$ sources; however, similar to experiment 1 , tibia $\mathrm{Zn}$ (concentration and total) in birds fed chelated $\mathrm{Zn}$ responded linearly only up to $15 \mathrm{mg} / \mathrm{kg}$ supplemental $\mathrm{Zn}$ (Figure 2A and $3 \mathrm{~A}$; and Table 4). Furthermore, tibia $\mathrm{Zn}$ concentration reached a similar plateau in both experiments, although this plateau was only reached with chelated $\mathrm{Zn}(147 \mu \mathrm{g} / \mathrm{g}$ in experiment $1 ; 149 \mu \mathrm{g} / \mathrm{g}$ in experiment 2; Figure 3A). Multiple linear regression slope-ratio analysis indicated that the slope of the total tibia $\mathrm{Zn}(\mu \mathrm{g})$ curve was $441 \%$ $(P=0.0063)$ for chelated $\mathrm{Zn}$ relative to $\mathrm{Zn}$ sulfate (Figure $2 \mathrm{~A}$ and Table 4), whereas the RBV estimate for tibia $\mathrm{Zn}$ concentration $(\mu \mathrm{g} / \mathrm{g})$ curve for chelated Zn (using only chelated Zn levels below the breakpoint) was $307 \%(P=0.0066)$ relative to $\mathrm{Zn}$ sulfate (Table 4). Slope-ratio analysis of small intestinal MT mRNA expression indicated that the estimated 


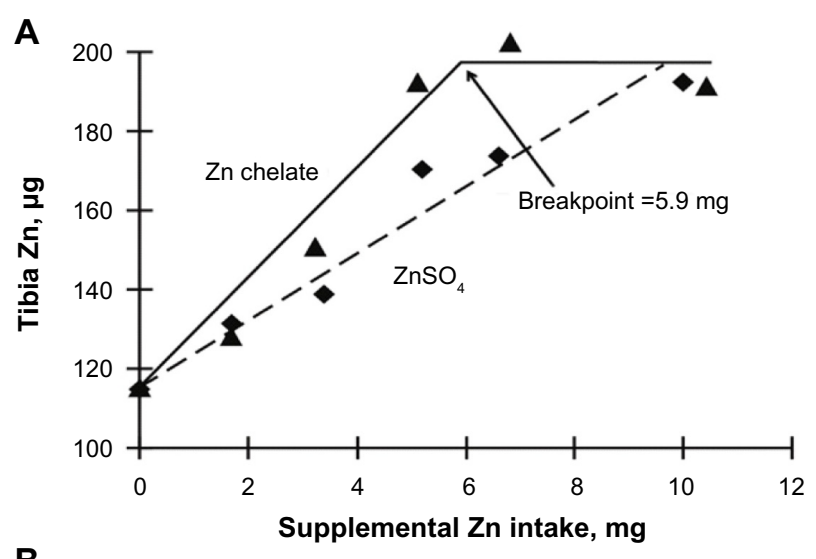

B

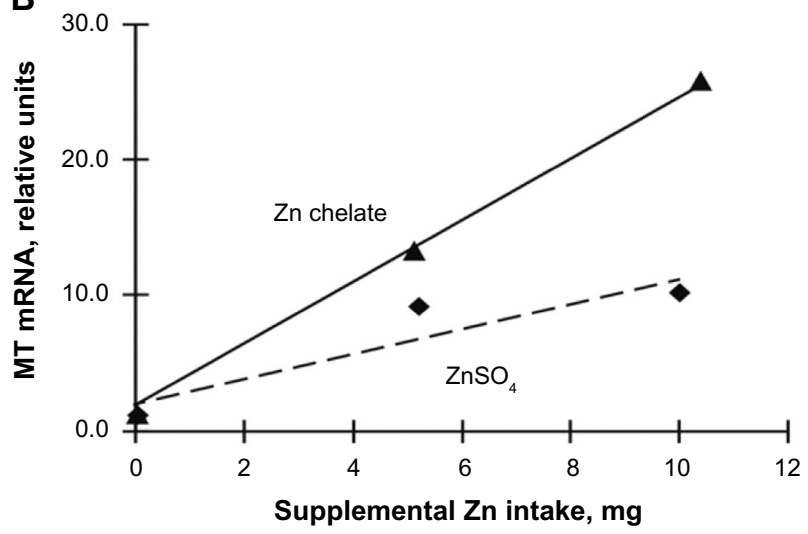

Figure I Regression of total tibia Zn $(\mu \mathrm{g})$ (A) or small intestinal MT mRNA expression (relative units) (B) on supplemental $\mathrm{Zn}$ intake $(\mathrm{mg})$ from $\mathrm{Zn}$ sulfate or from $\mathrm{Zn}$ chelate in chicks fed typical $\mathrm{Ca}$ and $\mathrm{P}$ levels (experiment $\mathrm{I}$ ).

Notes: $\mathrm{Zn}$ chelate was provided as $\mathrm{Zn}$ methionine hydroxy analog (Novus International Inc.). (A) For $\mathrm{Zn}$ sulfate, the relationship between tibia $\mathrm{Zn}$ and supplemental $Z n$ intake was linear $(P<0.000 \mathrm{I})$, whereas for $Z n$ chelate the relationship was quadratic $(P=0.0006)$. Breakpoints were determined using a model involving two linear splines with a plateau. The $\mathrm{x}$ and $\mathrm{y}$ coordinates for the inflection point determined for $\mathrm{Zn}$ chelate were $5.9 \mathrm{mg}$ and $196 \mu \mathrm{g}$, respectively. The breakpoint 5.9 corresponds to a total dietary concentration of $38.4 \mathrm{mg} / \mathrm{kg}$ of $\mathrm{Zn}$ for $\mathrm{Zn}$ chelate. Levels below the breakpoint for chelated $Z n$ and all levels of $Z n$ sulfate were used to determine the slope (total tibia $\mathrm{Zn}[\mu \mathrm{g}, \mathrm{Y}]$ regressed on supplemental $\mathrm{Zn}$ intake $[\mathrm{mg}])$ for $\mathrm{ZnSO}_{4}\left(X_{1}\right)$ and $\mathrm{Zn}$ chelate $\left(X_{2}\right)$ using multiple regression: $Y=1 \mid 3.7( \pm 4.3)$ $+8.66( \pm 0.87) \mathrm{X}_{1}+13.93( \pm \mathrm{I} .7 \mathrm{I}) \mathrm{X}_{2}, R^{2}=0.67(\mathrm{n}=66)$. Bioavailability of chelated $\mathrm{Zn}$ relative to $Z n$ sulfate $(100 \%)$ was $161 \%(P=0.001)$. (B) Multiple regression of small intestinal MT mRNA expression (relative units, $Y$ ) on supplemental $\mathrm{Zn}$ intake $(\mathrm{mg})$ from $\mathrm{Zn}$ sulfate $\left(X_{1}\right)$ and $\mathrm{Zn}$ chelate $\left(X_{2}\right)$ yielded the equation: $Y=1.82( \pm 2.55)+0.92$ $( \pm 0.46) \mathrm{X}_{1}+2.28( \pm 0.45) \mathrm{X}_{2}, R^{2}=0.44(\mathrm{n}=36)$. Bioavailability of chelated $\mathrm{Zn}$ relative to $\mathrm{Zn}$ sulfate $(100 \%)$ was $248 \%(P=0.009)$. For both panels $\mathbf{A}$ and $\mathbf{B}, \mathrm{n}=6$ replicate groups of eight male chicks per replicate for each treatment, except 12 replicate groups for the Zn-unsupplemented control.

Abbreviation: MT, metallothionein.

bioavailability of chelated $\mathrm{Zn}$ was $426 \%(P=0.0041)$ relative to $\mathrm{Zn}$ sulfate (Figure 2B and Table 4).

\section{Differential effects of $\mathrm{Ca} / \mathrm{P}$ excess on $\mathrm{Zn}$ source}

As shown in Figure 3A, the tibia $\mathrm{Zn}(\mu \mathrm{g} / \mathrm{g})$ slopes for $\mathrm{Zn}$ chelate were not different ( 8.32 and 9.97 for $\mathrm{Zn}$ chelate in experiments 1 and 2, respectively; $P=0.42$ ) between experiments 1 and 2 , indicating little or no antagonism by the elevated $\mathrm{Ca}$ and $\mathrm{P}$. In fact, the slope was numerically higher $(19.8 \%$ increase) in experiment 2 . In contrast, there was a $40 \%$ reduction in slope (4.86 and 2.91 in experiments 1 and 2, respectively; $P=0.086$ ) for $\mathrm{Zn}$ sulfate in the presence of elevated $\mathrm{Ca}$ and $\mathrm{P}$ (Figure 3B). Similar results were seen when total tibia $\mathrm{Zn}(\mu \mathrm{g})$ was compared (data not shown); the $\mathrm{Zn}$ sulfate bioavailability (slope 8.66 versus 2.89 for $\mathrm{ZnSO}_{4}$, experiments 1 versus 2, respectively; $P<0.0001$ ) was reduced by the antagonism much more dramatically $(66.6 \%$ reduction) than the $Z n$ chelate (slope 13.93 versus 12.77 for $\mathrm{Zn}$ chelate, experiments 1 versus 2 , respectively; $P=0.57$, or $8.3 \%$ reduction). These results suggest that the $\mathrm{Zn}$ sulfate was antagonized by elevated $\mathrm{Ca}$ and $\mathrm{P}$ to a much greater extent than the $\mathrm{Zn}$ chelate. Consistent with these results, the tibia Zn breakpoint (y coordinate) did not change appreciably in response to elevated $\mathrm{Ca}$ and $\mathrm{P}$ when the $\mathrm{Zn}$ chelate was fed (147 versus $149 \mu \mathrm{g} / \mathrm{g}$; Figure 3A). Although the x-breakpoint coordinates appear to be different (6.25 mg supplemental $\mathrm{Zn}$ in experiment 1 versus $3.46 \mathrm{mg}$ supplemental $\mathrm{Zn}$ in experiment 2), these breakpoints (based on total dietary concentrations) are, in fact, quite similar: 18 versus $16 \mathrm{mg}$ supplemental $\mathrm{Zn} / \mathrm{kg}$ diet, or 39 versus $43 \mathrm{mg}$ total $\mathrm{Zn} / \mathrm{kg}$ diet for experiments 1 and 2, respectively.

Note that a plateau for tibia $\mathrm{Zn}$ concentration was not reached for $\mathrm{Zn}$ sulfate in either trial, but if one assumes that the threshold for tibia $\mathrm{Zn}$ concentration when $\mathrm{Zn}$ sulfate is fed would be the same as it is when $\mathrm{Zn}$ chelate is fed $(148 \mu \mathrm{g} / \mathrm{g}$, the average of the y coordinate from breakpoint estimates obtained from Figure 3A), then one can calculate the amount of $\mathrm{Zn}$ sulfate required to meet this threshold from best-fit equations (see Figure 3 legend for equation). Our calculations indicate that in the presence of elevated $\mathrm{Ca}$ and $\mathrm{P}, 10.23 \mathrm{mg}$ supplemental $\mathrm{Zn}$ intake from $\mathrm{Zn}$ sulfate (equates to $46 \mathrm{mg}$ supplemental $\mathrm{Zn} / \mathrm{kg}$ diet or $73 \mathrm{mg}$ total $\mathrm{Zn} / \mathrm{kg}$ diet; experiment 2) would be necessary to reach this threshold, compared with only $3.46 \mathrm{mg}$ for $\mathrm{Zn}$ chelate. This represents a threefold difference in amount of $\mathrm{Zn}$ needed ( $\mathrm{Zn}$ sulfate versus $\mathrm{Zn}$ chelate) to maximize tibia $\mathrm{Zn}$ concentration ( $\mu \mathrm{g} / \mathrm{g}$ tibia). This estimate $(10.23 / 3.46=2.96$, or $296 \%)$ agrees closely with the $307 \%$ RBV estimate determined for tibia $\mathrm{Zn}$ concentration in experiment 2 by the slope-ratio methodology (Table 4). In the absence of elevated $\mathrm{Ca}$ and $\mathrm{P}$ (experiment 1), the amount of $\mathrm{Zn}$ sulfate necessary to maximize tibia $\mathrm{Zn}$ concentration was calculated to be $10.58 \mathrm{mg}$ supplemental $\mathrm{Zn}$, which equates to $32 \mathrm{mg}$ supplemental $\mathrm{Zn} / \mathrm{kg}$ diet or $53 \mathrm{mg}$ total $\mathrm{Zn} / \mathrm{kg}$ diet, whereas the plateau was reached at $6.25 \mathrm{mg}$ supplemental $\mathrm{Zn}$ intake for the $\mathrm{Zn}$ chelate (Figure 3A). Thus, the bioavailability for $\mathrm{Zn}$ chelate is calculated to be $(10.58 / 6.25=1.69)$ 
Table 4 Response of chicks fed graded levels of Zn sulfate or Zn chelate in a C-SBM diet with elevated Ca and P (experiment 2) ${ }^{\mathrm{a}, \mathrm{b}}$

\begin{tabular}{|c|c|c|c|c|c|c|c|c|}
\hline \multirow{2}{*}{$\begin{array}{l}\text { Supplemental } \\
\mathrm{Zn}, \mathrm{mg} / \mathrm{kg}\end{array}$} & \multirow{2}{*}{$\begin{array}{l}\text { Zn } \\
\text { source }^{d}\end{array}$} & \multirow{2}{*}{$\begin{array}{l}\text { Weight } \\
\text { gain, g }\end{array}$} & \multirow{2}{*}{$\begin{array}{l}\text { Gain:feed, } \\
\text { g/kg }\end{array}$} & \multirow{2}{*}{$\begin{array}{l}\text { Tibia } \\
\text { weight }^{c}, \mathrm{~g}\end{array}$} & \multirow{2}{*}{$\begin{array}{l}\text { Supplemental Zn } \\
\text { intake (day 14), } \\
\text { mg }^{\mathrm{e}-\mathrm{g}}\end{array}$} & \multicolumn{2}{|l|}{ Tibia $\mathbf{Z n}^{\mathrm{c}}$} & \multirow{2}{*}{$\begin{array}{l}\text { MT expression, } \\
\text { relative units }\end{array}$} \\
\hline & & & & & & $\begin{array}{l}\text { concentration } \\
\mu \mathrm{g} / \mathrm{g}^{\mathrm{e}}\end{array}$ & $\begin{array}{l}\text { total } \\
\mu g^{f}\end{array}$ & \\
\hline 0 & None & 158 & 666.0 & 0.99 & 0 & 117.5 & 115.4 & 1.0 \\
\hline 15 & $\mathrm{ZnSO}_{4}$ & 146 & 662.3 & 0.93 & 3.27 & 128.3 & 117.6 & 2.57 \\
\hline 30 & $\mathrm{ZnSO}_{4}$ & 149 & 662.5 & 0.96 & 6.64 & 137.7 & 130.2 & 2.71 \\
\hline 7.5 & Zn chelate & 164 & 674.8 & 1.06 & 1.80 & 127.4 & 136.0 & 3.34 \\
\hline 15 & Zn chelate & 143 & 637.2 & 0.97 & 3.25 & 146.8 & 150.5 & 2.88 \\
\hline 30 & Zn chelate & 138 & 669.0 & 0.91 & 6.06 & 149.2 & 134.6 & 12.39 \\
\hline Pooled SEM & & 8.6 & 17.7 & 0.05 & 0.22 & 6.5 & 9.2 & 2.14 \\
\hline
\end{tabular}

Notes: ${ }^{2}$ Data represent means of six replicate groups of eight male chicks during the period of $8-14$ days posthatching. Tibia $\mathrm{Zn}$ (both left and right) was measured in two birds per replicate on day 14. MT was measured in two birds per replicate on day II; ' $\mathrm{Zn}$, unsupplemented C-SBM diet contained $27 \mathrm{mg} / \mathrm{kg}$ of Zn, I.2\% Ca, and I.0\% available $\mathrm{P}$; ' $\mathrm{T}$ Tibia weight and $\mathrm{Zn}$ values are expressed on a dry-bone basis; ${ }^{d}$ both $\mathrm{ZnSO} \cdot \mathrm{H}_{2} \mathrm{O}$ and $\mathrm{Zn}$ chelate were provided as feed-grade sources. $\mathrm{Zn}$ chelate was in the form of $Z n$ methionine hydroxy analog (Novus International Inc.); eusing all levels of $Z n$ sulfate and the 0, 7.5, and I5 mg/kg diet $Z n$ levels of $Z n$ chelate, multiple regression of tibia $Z n$ concentration $(\mu \mathrm{g} / g, Y)$ on supplemental $Z n$ intake $(m g)$ from $Z n$ sulfate $\left(X_{1}\right)$ and chelated $Z n$ chelate $\left(X_{2}\right)$ was: $Y=I I 5 . I( \pm 5.40)+3.458( \pm I .285) X_{1}+I 0.612( \pm 2.856)$ $X_{2}, R^{2}=0.37(n=30)$. Bioavailability of chelated $Z n$ relative to $Z n$ sulfate $(100 \%)$ was $307 \%(P=0.0066)$; fusing all levels of $Z n$ sulfate and the $0,7.5$, and $I 5 \mathrm{mg} / \mathrm{kg}$ diet $Z n$ levels of $\mathrm{Zn}$ chelate, multiple regression of total tibia $\mathrm{Zn}(\mu \mathrm{g}, \mathrm{Y})$ on supplemental $\mathrm{Zn}$ intake $(\mathrm{mg})$ from $\mathrm{Zn}$ sulfate $\left(\mathrm{X}_{1}\right)$ and $\mathrm{Zn}$ chelate $\left(\mathrm{X}_{2}\right)$ was: $\mathrm{Y}=\mathrm{III} .48( \pm 7.40)+2.893( \pm \mathrm{I} .76 \mathrm{I})$ $X_{1}+12.774( \pm 3.912) X_{2}, R^{2}=0.30(n=30)$. Bioavailability of chelated $Z n$ relative to $Z n$ sulfate $(100 \%)$ was $441 \%$ ( $\left.P=0.0063\right)$; ${ }^{8}$ using all levels of $Z n$ sulfate and $Z n$ chelate, multiple regression of I8S-normalized MT expression (relative units, $Y$ ) on supplemental $Z n$ intake $(m g)$ from $Z n$ sulfate $\left(X_{1}\right)$ and $Z n$ chelate $\left(X_{2}\right)$ was: $Y=0.4 I( \pm I .8)+0.92( \pm 0.98) X_{1}$ $+3.92( \pm \mathrm{I} .10) \mathrm{X}_{2}, R^{2}=0.33(\mathrm{n}=36)$. Bioavailability of chelated $\mathrm{Zn}$ relative to $\mathrm{Zn}$ sulfate $(\mathrm{I} 00 \%)$ was $426 \%(P=0.004 \mathrm{I})$.

Abbreviations: C-SBM, corn-soybean meal; SEM, standard error of the mean; MT, metallothionein.

or $169 \%$, again in close agreement with the $165 \%$ calculated by the slope-ratio method. Table 5 compares the $\mathrm{Zn}$ bioavailability of $\mathrm{Zn}$ chelate relative to that of $\mathrm{Zn}$ sulfate as determined for tibia $\mathrm{Zn}$ (concentration and total) and small intestinal MT expression in experiments 1 and 2 using sloperatio methodology.

\section{Discussion}

The data from our study indicate that a chelated $\mathrm{Zn}$ form is more bioavailable than $\mathrm{Zn}$ sulfate in standard balanced diets, and the bioavailability of chelated $\mathrm{Zn}$ relative to $\mathrm{Zn}$ sulfate increases dramatically in the presence of added $\mathrm{Ca}$ and $\mathrm{P}$ as antagonists. Consistent with this finding, the tibia $\mathrm{Zn}$ data suggest that $\mathrm{Zn}$ sulfate appeared to be antagonized by elevated $\mathrm{Ca}$ and $\mathrm{P}$, but chelated $\mathrm{Zn}$ was not. Indeed, the slope for $\mathrm{Zn}$ sulfate was $40 \%$ lower in experiment 2 when compared with experiment 1 , suggesting the $\mathrm{Zn}$ sulfate was antagonized by excess $\mathrm{Ca}$ and $\mathrm{P}$. In contrast, the slope for chelated $\mathrm{Zn}$ was not different between experiment 2 and experiment 1 , indicating that the $\mathrm{Zn}$ chelate was not antagonized by excess $\mathrm{Ca}$ and $\mathrm{P}$. Collectively, these findings demonstrate the potential advantages of a chelated trace mineral over an inorganic salt, especially under dietary conditions where antagonisms are present.

With regard to plausible explanations for the observed difference in bioavailability, several possibilities exist. One theory, proposed by Kratzer and Vohra, is that chelates have the ability to compete with phytic acid or other antagonists such as $\mathrm{Ca}$ and $\mathrm{P}$, for its $\mathrm{Zn}$-binding capacity. ${ }^{51}$ The $\mathrm{Zn}$ contained within the chelate forms a soluble complex with
$\mathrm{Zn}$ and, consequently, is available to the animal. In contrast, once complexed with phytate or other divalent minerals, the $\mathrm{Zn}$ present in inorganic sources is functionally unavailable. Chelates have stronger chemical bonds relative to those in inorganic trace metals, ie, compare the coordinate, covalent bond formed between the two ligands and metal, versus ITMs possessing a weaker ionic bond. ${ }^{52}$ Thus, chelates are more resistant to antagonisms. An alternative possibility is that organic $\mathrm{Zn}$ sources are absorbed via peptide or amino acid transport systems, resulting in higher digestibility and bioavailability. ${ }^{53}$

The published data concerning advantages of OTM versus ITM bioavailability are mixed. Some publications report significantly greater bioavailabilities of certain OTMs compared with ITMs, ${ }^{24,31,54-56}$ whereas many report no differences. ${ }^{23-26,57}$ Indeed, Schlegel et al recently published a meta-analysis of RBV studies combining a variety of different organic $\mathrm{Zn}$ sources, and concluded that, overall, organic $\mathrm{Zn}$ sources are not different in bioavailability from inorganic sources. ${ }^{57}$ The chelated $\mathrm{Zn}$ used in the current study was not part of this meta-analysis. These inconsistencies could be due to differences in chemical characteristics (and thus bioavailability) between different OTM forms, or could merely be a reflection of flaws in experimental design that prevent the detection of real differences. It should be noted that the supplemental $\mathrm{Zn}$ levels in many of these experiments were beyond the linear response range, or above the tissue $\mathrm{Zn}$ breakpoint, which can minimize differences between sources. ${ }^{31,57,58}$ Multiple papers, for example, have reported no difference in RBV between Zn sulfate and Zn methionine when supplemented at 

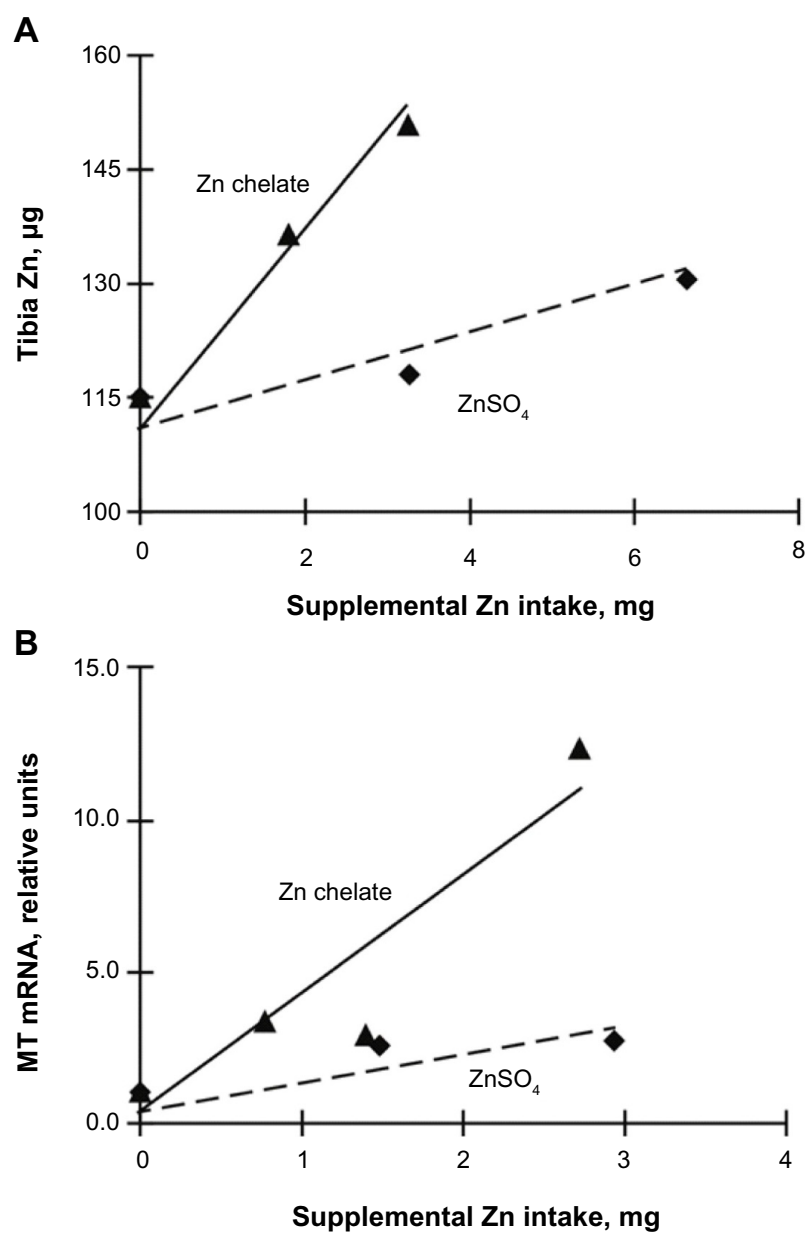

Figure 2 Regression of total tibia $\mathrm{Zn}(\mu \mathrm{g})(\mathbf{A})$ or small intestinal MT mRNA expression (relative units) (B) on supplemental $\mathrm{Zn}$ intake $(\mathrm{mg})$ from chicks fed elevated $\mathrm{Ca}$ and $\mathrm{P}$ (experiment 2).

Notes: $\mathrm{Zn}$ chelate was provided as $\mathrm{Zn}$ methionine hydroxy analog (Novus International Inc.). (A) Using all levels of $Z n$ sulfate and the $0,7.5$, and $15 \mathrm{mg} / \mathrm{kg} \mathrm{Zn}$ levels of $Z n$ chelate, multiple regression of total tibia $Z n(\mu g, Y)$ on supplemental $\mathrm{Zn}$ intake $(\mathrm{mg})$ from $\mathrm{Zn}$ sulfate $\left(\mathrm{X}_{1}\right)$ and $\mathrm{Zn}$ chelate $\left(\mathrm{X}_{2}\right)$ was: $\mathrm{Y}=\mathrm{II}$ I.48 $( \pm 7.40)$ $+2.893( \pm 1.761) X_{1}+12.774( \pm 3.912) X_{2}, R^{2}=0.30(n=30)$. Bioavailability of chelated $\mathrm{Zn}$ relative to $\mathrm{Zn}$ sulfate ( $100 \%)$ was $441 \%(P=0.0063)$. (B) Multiple regression of MT mRNA (relative units, $Y$ ) on supplemental $Z n$ intake $(\mathrm{mg})$ from $Z n$ sulfate $\left(X_{1}\right)$ and Zn chelate $\left(X_{2}\right)$ was: $Y=0.4 I( \pm 1.8)+0.92( \pm 0.98) X_{1}+3.92( \pm 1.10) X_{2}, R^{2}=0.33(n=36)$. Bioavailability of chelated $\mathrm{Zn}$ relative to $\mathrm{Zn}$ sulfate (I00\%) was $426 \%(P=0.004 \mathrm{I})$. For both panels $\mathbf{A}$ and $\mathbf{B}, \mathrm{n}=6$ replicate groups of eight male chicks per replicate for each treatment.

Abbreviation: MT, metallothionein.

high levels. ${ }^{31,34,57}$ The lack of difference in Zn bioavailability at high levels of supplementation is likely due to homeostatic mechanisms at the level of $\mathrm{Zn}$ absorption. Expression levels of $\mathrm{Zn}$ transporter proteins required for uptake (primarily Zip4 in humans and mice) and export (ZnT1) are both modulated by $\mathrm{Zn}$ status of the tissues. ${ }^{1,59-62} \mathrm{Zip}$ protein expression increases in deficiency and decreases at excess; the $\mathrm{ZnT}$ transporters are modulated in the opposite manner. When a given tissue (for example, the tibia) has reached peak $\mathrm{Zn}$ concentrations, net $\mathrm{Zn}$ uptake will decrease through these mechanisms. Thus, lack of a tibia $\mathrm{Zn}$ difference between $\mathrm{Zn}$
A

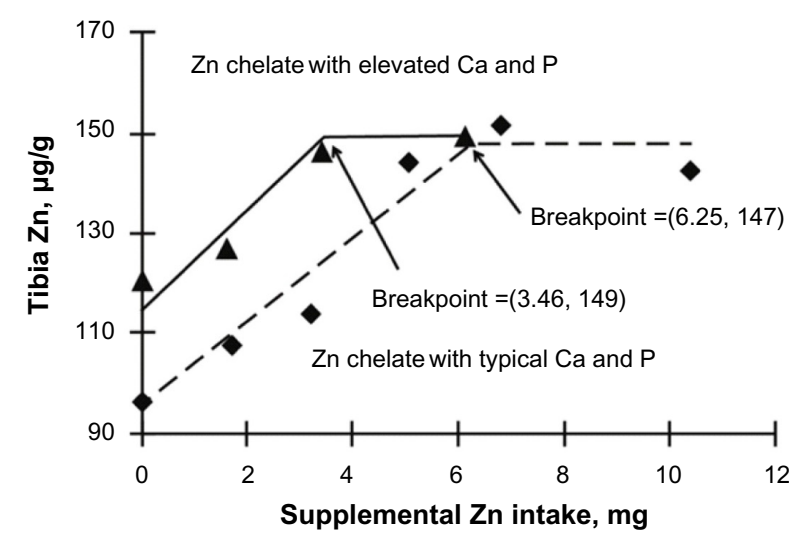

B

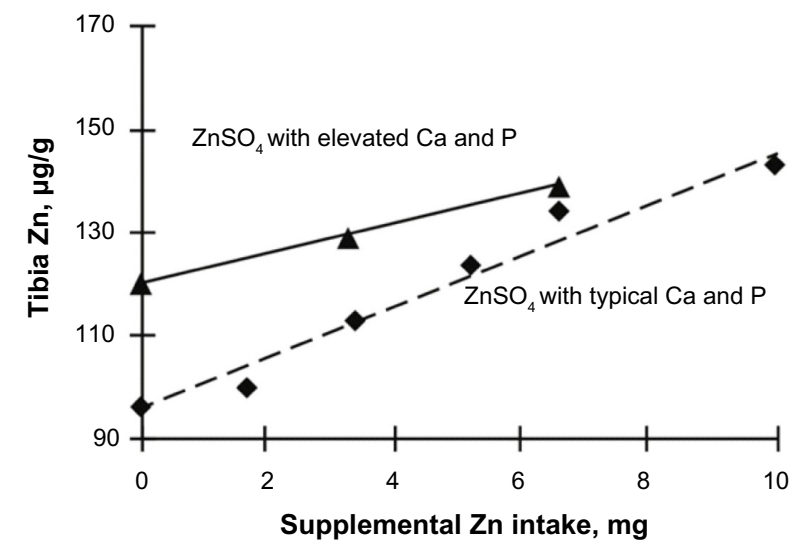

Figure 3 Regression of tibia Zn concentration $(\mu \mathrm{g} / \mathrm{g})$ on supplemental Zn intake (mg) from $\mathrm{Zn}$ chelate $(\mathbf{A})$ or $\mathrm{Zn}$ sulfate $(\mathbf{B})$ in chicks fed elevated $\mathrm{Ca}$ and $\mathrm{P}$ (experiment 2 ) or typical $\mathrm{Ca}$ and $\mathrm{P}$ levels (experiment $\mathrm{I}$ ).

Notes: $\mathrm{Zn}$ chelate was provided as $\mathrm{Zn}$ methionine hydroxy analog (Novus International Inc.). (A) For $Z n$ chelate, breakpoints were determined using a model involving two linear splines with a plateau. The maximum tibia $\mathrm{Zn}$ concentration $(\mu \mathrm{g} / \mathrm{g})$ achieved in both trials was similar [eg, the $\mathrm{Y}$ breakpoint coordinate was 147 $\mu \mathrm{g} / \mathrm{g}$ (experiment I) or $149 \mu \mathrm{g} / \mathrm{g}$ (experiment 2)]. The slopes for $\mathrm{Zn}$ chelate were also not different $(P=0.42)$ between experiments I and 2: 8.32 for experiment I (typical $\mathrm{Ca}$ and $\mathrm{P}$ ) and numerically higher (9.97) for experiment 2 (elevated $\mathrm{Ca}$ and $P$ ). Simple linear regression equations for experiments $I$ and 2 were $Y=95.4$ $+8.3226( \pm 1.10) X$, and $Y=114.5+9.9717( \pm 2.90) X$, respectively. The breakpoints $6.25 \mathrm{mg}$ (experiment I) and $3.46 \mathrm{mg}$ (experiment 2) of supplemental $\mathrm{Zn}$ correspond to total dietary concentrations of 39 and $43 \mathrm{mg}$ total $\mathrm{Zn} / \mathrm{kg}$ diet for experiments I and 2, respectively. (B) Regression of tibia $\mathrm{Zn}$ concentration ( $\mu \mathrm{g} / \mathrm{g}$ ) on supplemental $\mathrm{Zn}$ intake $(\mathrm{mg})$ from $\mathrm{Zn}$ sulfate in chicks fed elevated $\mathrm{Ca}$ and $\mathrm{P}$ (experiment 2 ) or typical $\mathrm{Ca}$ and $\mathrm{P}$ levels (experiment $\mathrm{I}$ ). For experiment $\mathrm{I}$, the regression equation was: $Y=96.6( \pm 2.5)+4.859( \pm 0.49) X, R^{2}=0.7 \mathrm{l}$. For experiment 2 , the regression equation was $Y=I 18.2( \pm 4.8)+2.913( \pm I . I I) X, R^{2}=0.30$. Simple linear regression was used to compare slopes between experiments $I$ and 2 , because intercepts were different $(P<0.000 \mathrm{I})$. Slopes also tended to be different $(P=0.086)$. This represents a $40 \%$ reduction in $Z n$ bioavailability for $Z n$ sulfate between experiments I and 2 .

sources at high levels of supplementation, above the tibia $\mathrm{Zn}$ inflection point, likely simply reflect a downregulation of net Zn import by that tissue rather than an inherent difference in bioavailability per se.

Faster growth rates of poultry and swine over the last two decades have been accompanied by substantial increases in the incidence and severity of a variety of skeletal and other 
Table 5 Relative bioavailability values (RBVs) of Zn from Zn chelate versus Zn sulfate as affected by Ca and P levela,b

\begin{tabular}{|c|c|c|c|c|c|c|c|c|c|c|}
\hline \multirow[t]{2}{*}{ Variable } & \multicolumn{3}{|c|}{ Experiment I (typical Ca and P) } & \multirow[t]{2}{*}{$P$-value } & \multirow[t]{2}{*}{$\mathbf{n}$} & \multicolumn{3}{|c|}{ Experiment 2 (elevated $\mathrm{Ca}$ and $\mathrm{P}$ ) } & \multirow[t]{2}{*}{$P$-value } & \multirow[t]{2}{*}{$\mathbf{n}$} \\
\hline & $\begin{array}{l}\mathrm{ZnSO}_{4} \\
\text { Slope } \pm \text { SE }\end{array}$ & $\begin{array}{l}\text { Zn chelate } \\
\text { Slope } \pm \text { SE }\end{array}$ & $\begin{array}{l}\mathbf{R B V}^{\mathbf{c}} \\
\%\end{array}$ & & & $\begin{array}{l}\mathrm{ZnSO}_{4} \\
\text { Slope } \pm \text { SE }\end{array}$ & $\begin{array}{l}\text { Zn chelate } \\
\text { Slope } \pm \text { SE }\end{array}$ & $\begin{array}{l}\mathbf{R B V}^{\mathbf{c}} \\
\%\end{array}$ & & \\
\hline Total tibia $\mathrm{Zn}, \mu \mathrm{g}$ & $8.66 \pm 0.87$ & $|3.93 \pm 1.7|$ & 161 & 0.001 & 66 & $2.89 \pm 1.76$ & $12.77 \pm 3.91$ & 441 & 0.0063 & 30 \\
\hline $\begin{array}{l}\text { Tibia Zn concentration, } \\
\mu \mathrm{g} / \mathrm{g}\end{array}$ & $5.00 \pm 0.53$ & $8.26 \pm 1.05$ & 165 & 0.0009 & 66 & $3.46 \pm 1.28$ & $10.61 \pm 2.86$ & 307 & 0.0066 & 30 \\
\hline $\begin{array}{l}\text { MT mRNA, } \\
\text { relative units }\end{array}$ & $0.92 \pm 0.46$ & $2.28 \pm 0.45$ & 248 & 0.009 & 36 & $0.92 \pm 0.98$ & $3.92 \pm 1.10$ & 426 & 0.0041 & 36 \\
\hline
\end{tabular}

Notes: aMultiple regression of total tibia $\mathrm{Zn}$, tibia $\mathrm{Zn}$ concentration, and MT mRNA expression in small intestine on supplemental Zn intake; Zn chelate, Zn methionine hydroxy analog chelate (Novus International Inc.); ' $\mathrm{Zn}$-unsupplemented corn-soybean meal diet contained $2 \mathrm{I} \mathrm{mg} \mathrm{Zn} / \mathrm{kg}$; $0.83 \% \mathrm{Ca}$ and $0.47 \%$ available $\mathrm{P}$ in experiment I. In experiment 2, the corn-soybean meal diet contained $27 \mathrm{mg} / \mathrm{kg} \mathrm{Zn}, \mathrm{I} .2 \% \mathrm{Ca}$, and I.0\% available P; cbioavailability of $\mathrm{Zn}$ sulfate set at $100 \%$.

Abbreviations: SE, standard error; MT, metallothionein.

structural problems, including lameness, bone breakage, tibial dyschondroplasia in poultry, and osteochondrosis in pigs, which are often attributed to poor mineral nutrition. ${ }^{63-66}$ As a result of these issues, trace minerals are often fed at levels that far exceed published NRC requirements. ${ }^{42}$ Despite higher feeding rates, these structural problems persist, likely due to poor mineral bioavailability and mineral-mineral antagonisms resulting from feeding high mineral concentrations. One might predict that feeding trace mineral forms that resist antagonism and are more bioavailable would reduce the incidence of these problems.

A minor limitation of most $\mathrm{Zn}$ bioavailability trials is that comparisons between $\mathrm{Zn}$ sources are made at deficient or marginal levels of $\mathrm{Zn}$ intake. Consequently, it is debated by some that the bioavailability estimates determined at deficient or marginal levels of $\mathrm{Zn}$ intake may not be applicable to commercial situations, wherein typical $\mathrm{Zn}$ levels exceed $\mathrm{Zn}$ requirements by two- to threefold..$^{42}$ Due to homeostatic mechanisms discussed previously (vide supra), little to no differences in bioavailability (as measured by bone Zn or MT) occur at dietary $\mathrm{Zn}$ intakes above the requirement, but the advantages in bioavailability are still evident in other biological measurements. Despite the lack of observed differences in this study between $\mathrm{Zn}$ sources for animal performance (eg, weight gain, feed intake) or bone $\mathrm{Zn}$ at levels above the breakpoint or commercially relevant $\mathrm{Zn}$ concentrations, the superior bioavailability of $\mathrm{Zn}$ chelate observed at low $\mathrm{Zn}$ intake is associated with numerous physiological benefits under commercial conditions. For example, significant advantages of chelated ZnHMTBa, in combination with $\mathrm{Mn}$ and CuHMTBa versus ITMs have been demonstrated in turkeys and broilers in field trials, wherein commercial levels of trace minerals were compared. In studies comparing iso- $\mathrm{Zn}$, $\mathrm{Cu}$, and Mn HMTBa versus ITMs, improvements included increased bone strength and width, improved foot pad score, reduced incidence of tibial dyschondroplasia, and reduced incidence of synovitis. ${ }^{2,67} \mathrm{In}$ addition, in a recent commercial broiler trial, birds fed reduced $\mathrm{Zn}, \mathrm{Cu}$, and $\mathrm{Mn}$ HMTBa (32, 8, and $32 \mathrm{mg} / \mathrm{kg}$ diet, respectively) had significantly improved footpad scores relative to broilers fed commercial levels of ITM $\mathrm{Zn}, \mathrm{Cu}$, and $\mathrm{Mn}(100,125$, and $90 \mathrm{mg} / \mathrm{kg}$ diet, respectively). ${ }^{68}$ Studies in broilers also demonstrated reductions in bacterial chondronecrosis with osteomyelitis with $\mathrm{Zn}, \mathrm{Cu}$, and Mn HMTBa supplementation (64:16:64 mg/kg diet, respectively) versus ITM $(100: 125: 90 \mathrm{mg} / \mathrm{kg}$ diet, respectively) ${ }^{69}$ It has recently been reported that sows fed a 50:50 mixture of OTM:ITMs ( $\mathrm{Zn}, \mathrm{Cu}$, and Mn HMTBa) exhibited a significant reduction in their overall culling rate when compared with control animals fed similar mineral concentrations as $100 \%$ inorganic mineral control (165:16:38 $\mathrm{mg} / \mathrm{kg}$ diet; $\mathrm{ZnO}, \mathrm{CuSO}_{4}$, and $\mathrm{MnO}$, respectively). ${ }^{70}$

In addition to improved skeletal integrity, chelated mineral sources also provide improved immunity, ${ }^{71-73}$ decreased oxidative stress, ${ }^{72,74}$ and decreased environmental burden. ${ }^{68}$ Furthermore, trace mineral studies comparing $\mathrm{Zn}, \mathrm{Cu}$, and $\mathrm{Mn}$ HMTBa (individually) versus corresponding sulfates in laying hens reported significant increases in eggshell thickness, Haugh units (a measure of increased egg white height associated with increased freshness and extended shelf-life), and enzyme activity including ceruloplasmin, carbonic anhydrase, and $\mathrm{Mn}$ superoxide dismutase. ${ }^{75}$ Thus, reported advantages of chelated minerals over inorganic mineral sources are related to improved structural and skeletal integrity, improved immune function, increased enzyme activity, and decreased oxidative stress. Given the marked changes that have occurred with today's commercial broilers and turkeys (eg, improved genetic selection, faster growth rates, and birds being grown to heavier market weights), it seems appropriate for future NRC poultry committees to consider recommending the use of chelated minerals for their demonstrated potential in reducing egg breakage (laying hens), tibial dyschondroplasia, synovitis, footpad lesions, chondronecrosis with osteomyelitis, and other issues associated with fast growth in poultry. 
Surprisingly, the tibia $\mathrm{Zn}$ concentrations were higher for birds fed the elevated $\mathrm{Ca}$ and $\mathrm{P}$ diets (experiment 2; unsupplemented or low $\mathrm{Zn}$ treatments) compared with birds fed normal $\mathrm{Ca}$ and $\mathrm{P}$ (experiment 1 ), until they reached a common plateau (Figure 3). The excesses of both $\mathrm{Ca}$ and $\mathrm{P}$ in experiment 2 reduced feed intake and body weight, resulting in smaller tibias and, given the similar tibia $\mathrm{Zn}$ content, a higher tibia $\mathrm{Zn}$ concentration. Similar tibia $\mathrm{Zn}$ concentrations $([\mu \mathrm{g} / \mathrm{g}]$, but not total tibia $\mathrm{Zn}[\mu \mathrm{g}]$ ), between the two experiments (at higher $\mathrm{Zn}$ intake) was not expected, but we believe this can be explained by differential partitioning of $\mathrm{Zn}$ to the tissues along with the homeostatic mechanisms discussed above. $\mathrm{Zn}$ deficiency in the young (eg, applies to livestock, pets, and humans) is characterized primarily by retardation of wholebody growth rather than by changes in tissue $\mathrm{Zn}$ content. ${ }^{76}$ With $\mathrm{Zn}$ deficiency, the body reduces intake in an attempt to maintain $\mathrm{Zn}$ concentrations in tissues: enzyme activity and organ/tissue concentrations are prioritized over growth. Zn concentrations of some tissues (eg, blood, hair, bone, testes, liver), but not others (eg, brain, lung, muscle, heart) are very sensitive to changes in $\mathrm{Zn}$ intake $;{ }^{76}$ consequently, $\mathrm{Zn}$ is partitioned, preferentially, to some tissues versus others. In chicks, for example, approximately $35 \%$ of whole-body $\mathrm{Zn}$ is stored in the bone, even though the bone only comprises $19 \%$ of dry body weight. ${ }^{77}$ Thus, we believe that, in the case of $\mathrm{Zn}$ deficiency imposed in experiment 2, $\mathrm{Zn}$ was preferentially targeted to the bone, likely at the expense of some other tissues, until it reached the plateau. In contrast to the differing tibia $\mathrm{Zn}$ concentrations in birds fed diets without supplemental $\mathrm{Zn}$, the plateau was very similar between experiments (147 versus $149 \mu \mathrm{g} / \mathrm{g}$ for tibia $\mathrm{Zn}$ concentration in experiments 1 and 2, respectively), suggesting that homeostatic mechanisms are working to ensure optimal concentrations of $\mathrm{Zn}$ in the bone.

Although no $\mathrm{Zn}$ source differences in weight gain, feed efficiency, or tibia weight were observed in experiments 1 and 2, there were significant differences in these measurements between experiments, most likely attributed to the excess of $\mathrm{Ca}$ and $\mathrm{P}$. It is widely known that excesses of $\mathrm{Ca}$ and $\mathrm{P}$ or imbalanced $\mathrm{Ca}: \mathrm{P}$ ratios depress weight gain. ${ }^{31,78}$ However, previous studies utilizing C-SBM diets have clearly demonstrated improved $\mathrm{Zn}$ status between ITM and OTM $\mathrm{Zn}$ sources, as measured by $\mathrm{Zn}$ bioavailability differences or antioxidant status, yet show no significant difference in animal performance (eg, bodyweight or weight gain). ${ }^{30,31,73}$ There were no skeletal issues or lameness observed in our studies, possibly due to the short duration of our study, and/or due to only a marginal Zn deficiency.
Dietary antagonists such as phytic acid, fiber, sulfates, high levels of other trace minerals such as $\mathrm{Cu}$, and potentially high levels of $\mathrm{Ca}$ and/or P are common in livestock diets. A Ca level of $4.5 \%$ is not uncommon in laying hen diets, nor is $1 \% \mathrm{Ca}$ uncommon in dairy diets, and high concentrations of $\mathrm{Ca}$ and $\mathrm{P}$ are commonly fed to turkeys. Elevated $\mathrm{Ca}$ and $\mathrm{P}$ levels are also prevalent in pet food. ${ }^{79}$ Based on a survey of 194 wet and dry dog foods, Ca concentrations ranged from $0.6 \%$ to $4.1 \%$ (mean $1.4 \%$; median $1.3 \%$ ) and P concentrations ranged from $0.4 \%$ to $2.4 \%$ (mean $1.1 \%$; median $1.0 \%$ ). In comparison, the dietary levels of $\mathrm{Ca}$ recommended by the Association of American Feed Control Officials (AAFCO), which sets nutrient guidelines for the pet food industry in the USA, and the NRC are $0.6 \%$ and $0.4 \%$, respectively; ${ }^{80,81}$ the dietary levels of P recommended by AAFCO and the NRC are $0.5 \%$ and $0.3 \%$, respectively. ${ }^{80,81}$ Similarly, based on a survey of 137 cat foods (wet and dry), Ca concentrations ranged from $0.5 \%$ to $3.5 \%$ (mean $1.3 \%$; median $1.2 \%$ ) and $\mathrm{P}$ concentrations ranged from $0.5 \%$ to $2.5 \%$ (mean $1.1 \%$; median 1.1\%). In comparison, the dietary levels of Ca recommended by AAFCO and the NRC are $0.6 \%$ and $0.29 \%$, respectively, ${ }^{80,81}$ and the dietary levels of $\mathrm{P}$ recommended by AAFCO and the NRC are $0.5 \%$ and $0.26 \%$, respectively. ${ }^{80,81}$ Thus, the levels of $\mathrm{Ca}$ and $\mathrm{P}$ evaluated in experiment 2 (eg, $1.2 \% \mathrm{Ca}, 1.3 \%$ total P, $1 \%$ available $\mathrm{P}$ ) would not be uncommon in commercial pet foods. As such, Zn deficiency in dogs and cats may be a concern. Indeed, studies have demonstrated higher $\mathrm{Zn}$ requirements in dog foods containing high levels of $\mathrm{Ca}$. One paper reported that puppies fed a standard diet containing $33 \mathrm{mg} \mathrm{Zn/kg}$ diet and 1.1\% Ca developed signs of $\mathrm{Zn}$ deficiency, whereas puppies fed the same level of $\mathrm{Zn}$ and $0.3 \% \mathrm{Ca}$ did not. ${ }^{82}$ Similarly, others induced a $\mathrm{Zn}$ deficiency in puppies fed $20-35 \mathrm{mg} \mathrm{Zn} / \mathrm{kg}$ diet and 2.64\% Ca ${ }^{83,84}$ Control puppies fed the same diet but supplemented with $120 \mathrm{mg} \mathrm{Zn/kg} \mathrm{diet} \mathrm{grew} \mathrm{normally} \mathrm{and} \mathrm{demonstrated} \mathrm{no}$ clinical signs of $Z n$ deficiency. There have also been a number of reports of naturally occurring $\mathrm{Zn}$ deficiency syndromes in dogs fed commercial dog foods. ${ }^{81} \mathrm{Zn}$ deficiency symptoms include poor growth rate and/or significant skin lesions, which initially occur in areas of contact or wear such as foot pads. ${ }^{82} \mathrm{AAFCO}$ recommends a $120 \mathrm{mg} \mathrm{Zn/kg} \mathrm{diet} \mathrm{for} \mathrm{dogs,}$ concentrations that are twofold higher than minimum NRC recommendations (eg, $60 \mathrm{mg} \mathrm{Zn/kg} \mathrm{diet),} \mathrm{probably} \mathrm{higher}$ because of the high $\mathrm{Ca}$ levels and/or phytate present in some commercial dog foods.$^{80}$ Collectively, these data suggest that certain dietary conditions (high $\mathrm{Ca}$ and $\mathrm{P}$ ) potentially induce $Z n$ deficiency in dogs and cats. Our data suggest that feeding a chelated $\mathrm{Zn}$ form could prevent antagonism-induced 
Zn deficiency. Interestingly, published data have shown that another chelated $\mathrm{Zn}$ form was able to resist $\mathrm{Ca}$-induced $\mathrm{Zn}$ antagonism in dogs. ${ }^{85}$

Our study had some limitations, strengths, and difficulties. One limitation was the lack of control treatments (typical $\mathrm{Ca}$ and $\mathrm{P}$ concentrations) in experiment 2. Our comparison of experiments 1 and 2 (Figure 3 ), for example, was confounded by trial. It would have been more appropriate to compare $\mathrm{Zn}$ bioavailability between $\mathrm{Zn}$ sources under dietary conditions of low $\mathrm{Ca} / \mathrm{P}$ versus elevated $\mathrm{Ca} / \mathrm{P}$ within the same trial. Nonetheless, other researchers, using similar C-SBM basal diets (without antagonists) and similar commercial poultry strains (Ross White versus Cobb 500 in our study), yielded similar linear response ranges, breakpoints, and slopes. Thus, the statistical methodology is repeatable between studies and different researchers; thus, we believe our comparisons between experiments 1 and 2 and our conclusions are valid. For example, Jondreville et al also utilized a linear plateau model to define breakpoints and slopes for tibia $\mathrm{Zn}$ concentration (expressed as $\mu \mathrm{g} / \mathrm{g}$ ) for $\mathrm{Zn}$ sulfate, and their results were in close agreement with our trial (eg, breakpoints were 51 versus $53 \mathrm{mg} \mathrm{Zn/kg} \mathrm{diet} \mathrm{(see} \mathrm{"Results";} \mathrm{the} \mathrm{breakpoint} \mathrm{for} \mathrm{Zn}$ sulfate was predicted, not determined in our study), and their slope for $\mathrm{Zn}$ sulfate was 4.48 versus 5.00 in our study). ${ }^{58}$

Despite these limitations, this study utilized robust experimental and statistical methodologies, in commercially relevant diets, to elucidate the bioavailability differences between a chelated $\mathrm{Zn}$ form and $\mathrm{Zn}$ sulfate. Defining the linear response range, the statistical design of our study, and use of C-SBM diets were some of the strengths of our study. Slope-ratio multiple regression analyses is a sensitive statistical methodology used to assess bioavailability (more powerful than pair-wise comparison procedures), but also has its difficulties, which we attempted, where possible, to address. A linear response range is necessary in order to compare slopes, and it is critical to define the response change in order to ensure treatment doses do not fall in the plateau range. In the case of C-SBM diets, it is especially difficult to formulate a $\mathrm{Zn}$-deficient diet. Typical $\mathrm{Zn}$ concentrations in SBM, in our experience, range from $44 \mathrm{mg}$ to $125 \mathrm{mg}$ $\mathrm{Zn} / \mathrm{kg}$; thus, it is necessary to screen multiple lots of SBM to identify lots low enough in $\mathrm{Zn}$ to create low Zn C-SBM basal diets. In our study, basal diets varied between $21 \mathrm{mg}$ and $27 \mathrm{mg} \mathrm{Zn/kg} \mathrm{diet;} \mathrm{the} \mathrm{breakpoint} \mathrm{for} \mathrm{bone} \mathrm{Zn}$ for chelated $\mathrm{Zn}$ was $38 \mathrm{mg} \mathrm{Zn/kg} \mathrm{diet,} \mathrm{so} \mathrm{the} \mathrm{linear} \mathrm{response} \mathrm{range} \mathrm{was}$ quite narrow (11-17 mg/kg Zn). Furthermore, due to the heterogeneity and low $\mathrm{Zn}$ concentrations of our diets, it can be difficult for analyzed $\mathrm{Zn}$ to agree closely with predicted values (analytical variance for $\mathrm{Zn}$ is $20 \%) .{ }^{80}$ It would be more convenient to use semi-purified diets for $\mathrm{Zn}$ bioavailability studies, thus achieving lower dietary Zn concentrations and wider response ranges. However, we believed it was critical that our experimental diets simulate commercially relevant diets in order to obtain data that would be meaningful in the real world. Additionally, the presence of phytate (common in cereal grains and legumes) is an important antagonism that reduces $\mathrm{Zn}$ bioavailability, thus maximizing bioavailability differences between inorganic and chelated Zn sources. For example, Wedekind et al compared the bioavailability of an OTM (Zn methionine) versus Zn sulfate in a purified amino acid diet devoid of phytate and fiber and also compared these same $\mathrm{Zn}$ sources in a C-SBM diet. ${ }^{31}$ The bioavailability of $\mathrm{Zn}$ methionine relative to $\mathrm{Zn}$ sulfate was markedly different (117\% in the amino acid diet and 206\% in the C-SBM diet). In the presence of antagonisms (ie, phytate, fiber, and/or elevated $\mathrm{Ca}$ and $\mathrm{P}$ ), bioavailability differences between OTMs and ITMs are increased. Thus, the basal diet used to assess $\mathrm{Zn}$ bioavailability is critical and dietary characteristics such as phytate, fiber, $\mathrm{Ca}$, and $\mathrm{P}$ levels, should simulate commercial conditions. Lastly, the advantages of chelated minerals are often overlooked. A recent meta-analysis concluded no differences between OTMs and ITMs. ${ }^{57}$ Thus, an additional strength of our study was, with careful attention to study details, our ability to show a bioavailability advantage of this particular Zn chelate versus $\mathrm{Zn}$ sulfate.

In summary, the bioavailability of a chelated $\mathrm{Zn}$ source relative to $\mathrm{Zn}$ sulfate was compared utilizing a $\mathrm{Zn}$ depletionrepletion model, with two measures of $\mathrm{Zn}$ bioavailability assessed (tibia $\mathrm{Zn}$ and MT mRNA). The results of this study indicate that chelated $\mathrm{Zn}$ provided more bioavailable $\mathrm{Zn}$ than inorganic $\mathrm{Zn}$. The greater bioavailability of chelated versus inorganic $\mathrm{Zn}$ sources under conditions of dietary antagonisms may be especially important to livestock and pets wherein high levels of $\mathrm{Ca}$ and $\mathrm{P}$ may be present. In addition, this advantage of chelates demonstrated under conditions of elevated $\mathrm{Ca}$ and P, may also be present under other dietary antagonisms, such as phytate, excess $\mathrm{Cu}$, excess $\mathrm{Fe}$, and others.

\section{Acknowledgments}

The authors wish to thank B Wuelling and M Wehmeyer for assisting with the conduct of the trial, and Cindy Atwell and Terra Wineman for assistance with sample collection.

\section{Disclosure}

PMF, JLE, and KJW are employees of Novus International Inc. (Saint Charles, MO, USA) which manufactures and 
markets OTM products, including Zn chelated to 2-hydroxy4-(methylthio)butanoic acid (Mintrex $\left.{ }^{\circledR} \mathrm{Zn}\right)$. JDR was an employee of Novus during the course of the study, analysis of the data, and preparation of the manuscript (current affiliation: Department of Global Regulatory and Nutrition Science, Mead Johnson Nutrition, Evansville, IN 47721 USA).

\section{References}

1. Blanchard RK, Moore JB, Green CL, Cousins RJ. Modulation of intestinal gene expression by dietary zinc status: effectiveness of cDNA arrays for expression profiling of a single nutrient deficiency. Proc Natl Acad Sci USA. 2001;98:13507-13513.

2. Dibner JJ, Richards JD, Kitchell ML, Quiroz MA. Metabolic challenges and early bone development. J Appl Poult Res. 2007;16:126-137.

3. Fraker PJ, King LE, Laakko T, Vollmer TL. The dynamic link between the integrity of the immune system and zinc status. J Nutr. 2000;130: 1399S-1406S.

4. MacDonald RS. The role of zinc in growth and cell proliferation. J Nutr. 2000;130:1500S-1508S.

5. Miao D, Liu H, Plut P et al. Impaired endochondral bone development and osteopenia in Gli2-deficient mice. Exp Cell Res. 2004;294: 210-222.

6. Powell SR. The antioxidant properties of zinc. J Nutr. 2000;130: 1447S-1454S.

7. Shankar AH, PrasadAS. Zinc and immune function: the biological basis of altered resistance to infection. Am J Clin Nutr. 1998;68:447S-463S.

8. Song Y, Leonard SW, Traber MG, Ho E. Zinc deficiency affects DNA damage, oxidative stress, antioxidant defenses, and DNA repair in rats. J Nutr. 2009;139:1626-1631.

9. Starcher BC, Hill CH, Madaras JG. Effect of zinc deficiency on bone collagenase and collagen turnover. J Nutr. 1980;110:2095-2102.

10. Underwood EJ, Suttle NF. The Mineral Nutrition of Livestock. 3rd ed. New York, NY, USA: CABI; 1999.

11. Vallee BL, Falchuk KH. The biochemical basis of zinc physiology. Physiol Rev. 1993;73:79-118.

12. Leeson S, Summers JD, Scott ML. Nutrition of the Chicken. 4th ed. Guelph, ON, Canada: University Books; 2001.

13. Oberleas D, Muhrer ME, O’Dell BL. Dietary metal-complexing agents and zinc availability in the rat. J Nutr. 1966;90:56-62.

14. Cabell CA, Earle IP. Additive effect of calcium and phosphorus on utilization of dietary zinc. J Anim Sci. 1965;24:800-804.

15. Heth DA, Becker WM, Hoekstra WG. Effect of calcium, phosphorus and zinc on zinc-65 absorption and turnover in rats fed semipurified diets. J Nutr. 1966;88:331-337.

16. O'Dell BL. Bioavailability of trace elements. Nutr Rev. 1984;42: 301-308.

17. Gibson RS. A historical review of progress in the assessment of dietary zinc intake as an indicator of population zinc status. Adv Nutr. 2012;3: $772-782$.

18. Greger JL. Effects of phosphorous-containing compounds on iron and zinc utilization. In: Kies C, editor. Nutritional Bioavailability of Iron. 1st ed. Washington, DC, USA: American Chemical Society; 1982.

19. Zemel MB, Bidari MT. Zinc, iron, and copper availability as affected by orthophosphates, polyphosphates, and calcium. J Food Sci. 1983;48: 567-569.

20. Roberson RH, Schaible PJ. The effect of elevated calcium and phosphorus levels on the zinc requirement of the chick. Poult Sci. 1960;39:837-840.

21. Pond WG, Walker EF Jr, Kirtland D. Weight gain, feed utilization and bone and liver mineral composition of pigs fed high or normal Ca-P diets from weaning to slaughter weight. J Anim Sci. 1975;41:1053-1056.

22. Pond WG, Walker EF Jr, Kirtland D. Effect of dietary Ca and P levels from 40 to $100 \mathrm{Kg}$ body weight on weight gain and bone and soft tissue mineral concentrations. J Anim Sci. 1978;46:686-691.
23. Baker DH, Ammerman CB. Zinc bioavailability. In: Ammerman CB, Baker DH, Lewis AJ, editors. Bioavailability of Nutrients for Animals: Amino Acids, Minerals, and Vitamins. 1st ed. San Diego, CA, USA: Academic Press; 1995.

24. Cao J, Henry PR, Guo R, et al. Chemical characteristics and relative bioavailability of supplemental organic zinc sources for poultry and ruminants. J Anim Sci. 2000;78:2039-2054.

25. Huang YL, Lu L, Li SF, Luo XG, Liu B. Relative bioavailabilities of organic zinc sources with different chelation strengths for broilers fed a conventional corn-soybean meal diet. J Anim Sci. 2009;87:2038-2046.

26. Mohanna C, Nys Y. Effect of dietary zinc content and sources on the growth, body zinc deposition and retention, zinc excretion and immune response in chickens. Br Poult Sci. 1999;40:108-114.

27. Ammerman CB, Baker DH, Lewis AJ. Introduction to bioavailability of nutrients for animals. In: Ammerman CB, Baker DH, Lewis AJ, editors. Bioavailability of Nutrients for Animals: Amino Acids, Minerals, and Vitamins. 1st ed. San Diego, CA, USA: Academic Press; 1995.

28. Cao J, Henry PR, Davis SR, et al. Relative bioavailability of organic zinc sources based on tissue zinc and metallothionein in chicks fed conventional dietary zinc concentrations. Anim Feed Sci Technol. 2002;101:161-170.

29. Sandoval M, Henry PR, Ammerman CB, Miles RD, Littell RC. Relative bioavailability of supplemental inorganic zinc sources for chicks. J Anim Sci. 1997;75:3195-3205.

30. Wedekind KJ, Baker DH. Zinc bioavailability in feed-grade sources of zinc. J Anim Sci. 1990;68:684-689.

31. Wedekind KJ, Hortin AE, Baker DH. Methodology for assessing zinc bioavailability: efficacy estimates for zinc-methionine, zinc sulfate, and zinc oxide. J Anim Sci. 1992;70:178-187.

32. Aydemir TB, Blanchard RK, Cousins RJ. Zinc supplementation of young men alters metallothionein, zinc transporter, and cytokine gene expression in leukocyte populations. Proc Natl Acad Sci U S A. 2006;103: 1699-1704.

33. Bittel D, Dalton T, Samson SL, Gedamu L, Andrews GK. The DNA binding activity of metal response element-binding transcription factor-1 is activated in vivo and in vitro by zinc, but not by other transition metals. J Biol Chem. 1998;273:7127-7133.

34. Cao J, Cousins RJ. Metallothionein mRNA in monocytes and peripheral blood mononuclear cells and in cells from dried blood spots increases after zinc supplementation of men. J Nutr. 2000;130:2180-2187.

35. Carlson D, Beattie JH, Poulsen HD. Assessment of zinc and copper status in weaned piglets in relation to dietary zinc and copper supply. J Anim Physiol Anim Nutr (Berl). 2007;91:19-28.

36. Davis SR, Cousins RJ. Metallothionein expression in animals: a physiological perspective on function. J Nutr. 2000;130:1085-1088.

37. Martinez MM, Hill GM, Link JE, Raney NE, Tempelman RJ, Ernst CW. Pharmacological zinc and phytase supplementation enhance metallothionein mRNA abundance and protein concentration in newly weaned pigs. J Nutr. 2004;134:538-544.

38. McCormick CC, Menard MP, Cousins RJ. Induction of hepatic metallothionein by feeding zinc to rats of depleted zinc status. Am J Physiol. 1981;240:E414-E421.

39. Rojas LX, McDowell LR, Cousins RJ, et al. Relative bioavailability of two organic and two inorganic zinc sources fed to sheep. J Anim Sci. 1995;73:1202-1207.

40. Sullivan VK, Burnett FR, Cousins RJ. Metallothionein expression is increased in monocytes and erythrocytes of young men during zinc supplementation. J Nutr. 1998;128:707-713.

41. Driver JP, Pesti GM, Bakalli RI, Edwards HM Jr. Calcium requirements of the modern broiler chicken as influenced by dietary protein and age. Poult Sci. 2005;84:1629-1639.

42. National Research Council (US), Subcommittee on Poultry Nutrition. Nutrient Requirements of Poultry. 9th ed. Washington, DC, USA: National Academy Press; 1994.

43. Association of Official Agricultural Chemists International. Official Methods of Analysis of AOAC International. 18th ed. Gaithersburg, MD, USA: Association of Official Agricultural Chemists International; 2005. 
44. Reeves PG. Adaptation responses in rats to long-term feeding of highzinc diets: emphasis on intestinal metallothionein. J Nutr Biochem. 1995;6:48-54.

45. Szczurek EI, Bjornsson CS, Taylor CG. Dietary zinc deficiency and repletion modulate metallothionein immunolocalization and concentration in small intestine and liver of rats. J Nutr. 2001;131:2132-2138.

46. SAS Institute. SAS User's Guide. 9th ed. Cary, NC, USA: SAS Institute; 2003.

47. Finney DJ. Statistical Method of Biological Assay. 3rd ed. London, UK: Charles Griffith; 1978.

48. Draper NR, Smith H. Applied Regression Analysis. 2nd ed. New York, NY, USA: John Wiley and Sons; 1981.

49. Littell RC, Stroup WW, Freund RJ. SAS for Linear Models. 4th ed. Cary, NC, USA: SAS Institute; 2002.

50. Robbins KR, Saxton AM, Southern LL. Estimation of nutrient requirements using broken-line regression analysis. J Anim Sci. 2006;84 Suppl:E155-E165.

51. Kratzer FH, Vohra P. Chelates in Nutrition. Boca Raton, FL, USA: CRC Press; 1986.

52. Ashmead D. The need for chelated trace minerals. Vet Med Small Anim Clin. 1974;69:467-468.

53. Nitrayova S, Windisch W, von Heimendahl E, Muller A, Bartelt J. Bioavailability of zinc from different sources in pigs. J Anim Sci. 2012;90(Suppl 4):185-187.

54. Fly AD, Izquierdo OA, Lowry KR, Baker DH. Manganese bioavailability in a Mn-methionine chelate. Nutr Res. 1989;9:901-910.

55. Wedekind KJ, Lowry SR. Are organic zinc sources efficacious in puppies? J Nutr. 1998;128:2593S-2595S.

56. Yan F, Waldroup PW. Evaluation of Mintrex ${ }^{\circledR}$ manganese as a source of manganese for young broilers. Int J Poult Sci. 2006;5:708-713.

57. Schlegel P, Sauvant D, Jondreville C. Bioavailability of zinc sources and their interaction with phytates in broilers and piglets. Animal. 2013;7:47-59.

58. Jondreville C, Lescoat P, Magnin M, Feuerstein D, Gruenberg B, Nys Y. Sparing effect of microbial phytase on zinc supplementation in maizesoya-bean meal diets for chickens. Animal. 2007;1:804-811.

59. Dufner-Beattie J, Wang F, Kuo YM, Gitschier J, Eide D, Andrews GK. The acrodermatitis enteropathica gene ZIP4 encodes a tissue-specific, zincregulated zinc transporter in mice. J Biol Chem. 2003;278:33474-33481.

60. Eide DJ. The SLC39 family of metal ion transporters. Pflugers Arch. 2004;447:796-800.

61. Liuzzi JP, Cousins RJ. Mammalian zinc transporters. Annu Rev Nutr. 2004;24:151-172.

62. Cousins RJ, Liuzzi JP, Lichten LA. Mammalian zinc transport, trafficking, and signals. J Biol Chem. 2006;281:24085-24089.

63. Lilburn MS. Skeletal growth of commercial poultry species. Poult Sci. 1994;73:897-903.

64. Orth MW. The regulation of growth plate cartilage turnover. J Anim Sci. 1999;77 Suppl 2:183-189.

65. Julian RJ. Production and growth related disorders and other metabolic diseases of poultry - a review. Vet J. 2005;169:350-369.

66. Frantz NZ, Andrews GA, Tokach MD, et al. Effect of dietary nutrients on osteochondrosis lesions and cartilage properties in pigs. Am J Vet Res. 2008;69:617-624.

67. Ferket PR, Oviedo-Rondon EO, Mente PL, et al. Organic trace minerals and 25-hydroxycholecalciferol affect performance characteristics, leg abnormalities, and biomechanical properties of leg bones of turkeys. Poult Sci. 2009;88:118-131.

68. Manangi MK, Vazquez-Añon M, Richards JD, Carter S, Buresh RE, Christensen KD. Impact of feeding lower levels of chelated trace minerals vs industry levels of inorganic trace minerals on broiler performance, yield, foot pad health, and litter mineral concentration. J Appl Poult Res. 2012;21:881-890.
69. Chen J, Richards JD, Wedekind KJ, Manangi MK, Wideman RF, Dibner JJ. Effect of trace minerals on the development of bacterial chondronecrosis with osteomyelitis in poultry. Poster presentation at the Annual Meeting of the Poultry Science Association. July 14-17, 2014, Corpus Christi, TX, USA.

70. Wedekind KJ, Coverdale JA, Hampton TR, et al. Efficacy of an equine joint supplement, and the synergistic effect of its active ingredients (chelated trace minerals and natural eggshell membrane) as demonstrated in equine, swine, and an osteoarthritis rat model. Open Access Animal Physiology. 2015;7:13-27.

71. Dibner JJ, editor. Early nutrition of zinc and copper in chicks and poults: impact on growth and immune function. 3rd Mid-Atlantic Nutrition Conference. College Park, MD, USA: Maryland Feed Industry Council and University of Maryland; March 24, 2005.

72. Richards JD, Zhao J, Harrell RJ, Atwell CA, Dibner JJ. Trace mineral nutrition in poultry and swine. Asian Aust J Anim Sci. 2010;23:1527-1534

73. Bun SD, Guo YM, Guo FC, Ji FJ, Cao H. Influence of organic zinc supplementation on the antioxidant status and immune responses of broilers challenged with Eimeria tenella. Poult Sci. 2011;90:1220-1226.

74. Sun Q, Guo Y, Ma S, Yuan J, An S, Li J. Dietary mineral sources altered lipid and antioxidant profiles in broiler breeders and posthatch growth of their offsprings. Biol Trace Elem Res. 2012;145:318-324.

75. Sun Q, Guo Y, Li J, Zhang T, Wen J. Effects of methionine hydroxy analog chelated $\mathrm{Cu} / \mathrm{Mn} / \mathrm{Zn}$ on laying performance, egg quality, enzyme activity and mineral retention of laying hens. J Poult Sci. 2012;49:20-25.

76. Hambidge KM, Casey CE, Krebs NF. Zinc. In: Mertz W, editor. Trace Elements in Human and Animal Nutrition. 1st ed. Orlando, FL, USA: Academic Press; 1986.

77. Mavromichalis I, Emmert JL, Aoyagi S, Baker DH. Chemical composition of whole body, tissues, and organs of young chickens (Gallus domesticus). J Food Comp Anal. 2000;13:799-807.

78. Wedekind KJ, Titgemeyer EC, Twardock AR, Baker DH. Phosphorus, but not calcium, affects manganese absorption and turnover in chicks. J Nutr. 1991;121:1776-1786.

79. Hand MS, Thatcher CD, Remillard RL, Roudebush P, editors. Small Animal Clinical Nutrition. 4th ed. Topeka, KS, USA: Mark Morris Institute; 2000.

80. Association of American Feed Control Officials. AAFCO 2015 Official Publication. Champaign, IL, USA: Association of American Feed Control Officials; 2015.

81. National Research Council (US), Ad Hoc Committee on Dog and Cat Nutrition. Minerals. In: Nutrient Requirements of Dogs and Cats. Washington, DC, USA: National Academies Press; 2006.

82. Robertson BT, Burns MJ. Zinc metabolism and the zinc-deficiency syndrome in the dog. Am J Vet Res. 1963;24:997-1002.

83. Sanecki RK, Corbin JE, Forbes RM. Tissue changes in dogs fed a zincdeficient ration. Am J Vet Res. 1982;43:1642-1646.

84. Sanecki RK, Corbin JE, Forbes RM. Extracutaneous histologic changes accompanying zinc deficiency in pups. Am J Vet Res. 1985;46:2120-2123.

85. Lowe JA, Wiseman J, Cole DJ. Zinc source influences zinc retention in hair and hair growth in the dog. J Nutr. 1994;124:2575S-2576S.

86. Boling SD, Douglas MW, Johnson ML, et al. The effects of dietary available phosphorus levels and phytase on performance of young and older laying hens. Poult Sci. 2000;79:224-230. 


\section{Publish your work in this journal}

Open Access Animal Physiology is an international, peer-reviewed, open access journal publishing original research, reports, reviews

quick and fair peer-review system. Visit http://www.dovepress.com/ and commentaries on all areas of animal physiology. The manutestimonials.php to read real quotes from published authors. 